\title{
Horizontal and vertical structure of reactive bromine events probed by bromine monoxide MAX-DOAS
}

\author{
William R. Simpson ${ }^{1}$, Peter K. Peterson ${ }^{2}$, Udo Frieß ${ }^{3}$, Holger Sihler $^{4}$, Johannes Lampel ${ }^{3,4}$, Ulrich Platt ${ }^{3}$, \\ Chris Moore $^{5}$, Kerri Pratt ${ }^{2}$, Paul Shepson ${ }^{6}$, John Halfacre ${ }^{6, a}$, and Son V. Nghiem ${ }^{7}$ \\ ${ }^{1}$ Geophysical Institute and Department of Chemistry and Biochemistry, University of Alaska Fairbanks, \\ Fairbanks, AK 99775, USA \\ ${ }^{2}$ Department of Chemistry, University of Michigan, Ann Arbor, MI, USA \\ ${ }^{3}$ Institute of Environmental Physics, University of Heidelberg, Heidelberg, Germany \\ ${ }^{4}$ Satellite Remote Sensing Group, Max Planck Institute for Chemistry, Mainz, Germany \\ ${ }^{5}$ Gas Technology Institute, Des Plaines, IL, USA \\ ${ }^{6}$ Department of Chemistry, Purdue University, West Lafayette, IN, USA \\ ${ }^{7}$ Jet Propulsion Laboratory, California Institute of Technology, Pasadena, CA, USA \\ a current address: Department of Chemistry, Indiana University Southeast, New Albany, IN, USA \\ Correspondence to: William R. Simpson (wrsimpson@alaska.edu)
}

Received: 1 March 2017 - Discussion started: 3 March 2017

Revised: 15 June 2017 - Accepted: 28 June 2017 - Published: 4 August 2017

\begin{abstract}
Heterogeneous photochemistry converts bromide $\left(\mathrm{Br}^{-}\right)$to reactive bromine species $(\mathrm{Br}$ atoms and bromine monoxide, $\mathrm{BrO}$ ) that dominate Arctic springtime chemistry. This phenomenon has many impacts such as boundarylayer ozone depletion, mercury oxidation and deposition, and modification of the fate of hydrocarbon species. To study environmental controls on reactive bromine events, the BRomine, Ozone, and Mercury EXperiment (BROMEX) was carried out from early March to mid-April 2012 near Barrow (Utqiaġvik), Alaska. We measured horizontal and vertical gradients in $\mathrm{BrO}$ with multiple-axis differential optical absorption spectroscopy (MAX-DOAS) instrumentation at three sites, two mobile and one fixed. During the campaign, a large crack in the sea ice (an open lead) formed pushing one instrument package $\sim 250 \mathrm{~km}$ downwind from Barrow (Utqiagivik). Convection associated with the open lead converted the BrO vertical structure from a surfacebased event to a lofted event downwind of the lead influence. The column abundance of $\mathrm{BrO}$ downwind of the refreezing lead was comparable to upwind amounts, indicating direct reactions on frost flowers or open seawater was not a major reactive bromine source. When these three sites were separated by $\sim 30 \mathrm{~km}$ length scales of unbroken sea ice, the $\mathrm{BrO}$ amount and vertical distributions were highly corre-
\end{abstract}

lated for most of the time, indicating the horizontal length scales of BrO events were typically larger than $\sim 30 \mathrm{~km}$ in the absence of sea ice features. Although $\mathrm{BrO}$ amount and vertical distribution were similar between sites most of the time, rapid changes in $\mathrm{BrO}$ with edges significantly smaller than this $\sim 30 \mathrm{~km}$ length scale episodically transported between the sites, indicating $\mathrm{BrO}$ events were large but with sharp edge contrasts. BrO was often found in shallow layers that recycled reactive bromine via heterogeneous reactions on snowpack. Episodically, these surface-based events propagated aloft when aerosol extinction was higher $\left(>0.1 \mathrm{~km}^{-1}\right)$; however, the presence of aerosol particles aloft was not sufficient to produce $\mathrm{BrO}$ aloft. Highly depleted ozone $\left(<1 \mathrm{nmol} \mathrm{mol}^{-1}\right)$ repartitioned reactive bromine away from $\mathrm{BrO}$ and drove $\mathrm{BrO}$ events aloft in cases. This work demonstrates the interplay between atmospheric mixing and heterogeneous chemistry that affects the vertical structure and horizontal extent of reactive bromine events. 


\section{Introduction}

During Arctic spring, photochemical reactions on snow, ice, and aerosol particle surfaces convert, and may also recycle, halide anions that originate from sea salts to potent halogen oxidizers that cause ozone depletion events (Barrie et al., 1988; Simpson et al., 2007b), oxidize hydrocarbons (Jobson et al., 1994; Gilman et al., 2010; Hornbrook et al., 2016), and oxidize mercury (Schroeder et al., 1998; Steffen et al., 2008), leading to enhanced deposition of pollutants to the Arctic. This chemistry depends upon the presence of sea ice, which is rapidly changing (Nghiem et al., 2007, 2013; Stroeve et al., 2012), but understanding of environmental controls (Abbatt et al., 2012; Simpson et al., 2015) on this chemical process is very limited.

Satellite remote sensing has detected enhanced bromine monoxide (BrO) during Arctic spring (Richter et al., 1998; Wagner and Platt, 1998), but satellite-detected hot spots were sometimes not observed by in situ aircraft studies (Jacob et al., 2010; Salawitch et al., 2010). Satellite-observed BrO was correlated with high winds (Jones et al., 2009; Choi et al., 2012) and potential frost flowers (Kaleschke et al., 2004), while ground-based studies found little relationship between $\mathrm{BrO}$ and these proxy measurements (Simpson et al., 2007a; Halfacre et al., 2014; Peterson et al., 2016). To investigate these aspects of springtime reactive bromine chemistry, we carried out the BRomine, Ozone, and Mercury EXperiment (BROMEX) (Nghiem et al., 2013) near Barrow (Utqiagivik), Alaska, in spring 2012. This study provided an unprecedented opportunity to investigate the relationship between sea ice and atmospheric chemical processes.

Past work has demonstrated that $\mathrm{BrO}$ is related to ozone abundance (Simpson et al., 2007a; Helmig et al., 2012; Peterson et al., 2015), snowpack composition and pH (Simpson et al., 2005; Grannas et al., 2007; Krnavek et al., 2012; Pratt et al., 2013), aerosol particles (Frieß et al., 2011), and atmospheric stability (Peterson et al., 2015). Also during BROMEX, Moore et al. (2014) demonstrated that sea ice leads caused vertical mixing that brought ozone and mercury down from aloft. Peterson et al. (2015) expanded the idea that vertical mixing was important by showing that $\mathrm{BrO}$ vertical profiles were affected by atmospheric stability, finding that temperature inversions were correlated to shallow $\mathrm{BrO}$ layers. Pratt et al. (2013) showed that halogen activation was efficient in snowpack if that snow was acidic and had enriched $\mathrm{Br}^{-} / \mathrm{Cl}^{-}$ratios. Frieß et al. (2011) showed that $\mathrm{BrO}$ was more likely to be elevated in cases where aerosol particles were present (as indicated by aerosol extinction measurements) and suggested that aerosol production from blowing snow (Yang et al., 2010) may have been responsible.

A particular aspect needing consideration for $\mathrm{BrO}$ observations is $\mathrm{BrO}_{x}\left(\mathrm{BrO}_{x}=\mathrm{BrO}+\mathrm{Br}\right)$ repartitioning that occurs at low ozone mixing ratios (MRs). The two fastest reactions for the $\mathrm{BrO}_{x}$ family are $\mathrm{BrO}$ photolysis (Reaction $\mathrm{R} 1$ ) and reaction of $\mathrm{Br}$ with ozone (Reaction $\mathrm{R} 2$ ):

$\mathrm{BrO}+h v \rightarrow \mathrm{Br}+\mathrm{O}$

$\mathrm{Br}+\mathrm{O}_{3} \rightarrow \mathrm{BrO}+\mathrm{O}_{2}$.

These two reactions interconvert $\mathrm{BrO}_{x}$ family members but do not change $\mathrm{BrO}_{x}$ abundance. When ozone is depleted to levels $\sim 1-2 \mathrm{nmol} \mathrm{mol}^{-1}$, and for near-noon photolysis conditions, these reactions are of roughly equal rates. Therefore, when ozone goes below a few nanomoles per mole $\left(\mathrm{nmol} \mathrm{mol}{ }^{-1}\right)$, reactive bromine $\left(\mathrm{BrO}_{x}\right)$ may be present, but not all of that $\mathrm{BrO}_{x}$ is spectroscopically visible as $\mathrm{BrO} . \mathrm{BrO}_{x}$ is instead present as $\mathrm{Br}$ atoms, which rapidly oxidize mercury (Holmes et al., 2006, 2009; Stephens et al., 2012; Moore et al., 2014), affecting the fate of this pollutant. This low-ozoneinduced $\mathrm{BrO}_{x}$ repartitioning has been observed as decreased surface $\mathrm{BrO}$ during very low surface ozone periods in multiple field studies (Simpson et al., 2007a; Helmig et al., 2012; Peterson et al., 2015) and is a common feature of chemical modeling studies (Sander et al., 1997; Evans, 2003; Thomas et al., 2011; Toyota et al., 2014).

In the BROMEX study, we used multiple-axis differential optical absorption spectroscopy (MAX-DOAS) instruments deployed via helicopter in an upwind-downwind array to determine typical horizontal length scale and vertical structure of $\mathrm{BrO}$ events. These gradient observations complement Peterson et al. (2017), who used airborne DOAS to study an episode of reactive halogen transport. Here, we use these observations to study $\mathrm{BrO}$ spatial structures and the effects of sea-ice-lead-induced vertical mixing on reactive bromine.

\section{Methods}

\subsection{MAX-DOAS spectroscopy and analysis}

$\mathrm{BrO}$ and aerosol optical properties inferred from oxygen collisional dimer $\left(\mathrm{O}_{2}-\mathrm{O}_{2}\right.$ or $\left.\mathrm{O}_{4}\right)$ absorption were measured by MAX-DOAS spectroscopy, as described in Peterson et al. (2015), who adapted the methods of Frieß et al. (2011); see the Supplement for details. Three MAX-DOAS instruments of design similar to that described in prior references (Carlson et al., 2010; Peterson et al., 2016) were used. Two of the MAX-DOAS instruments were housed on mobile solarpowered instrument packages called "IceLanders" that were deployed by helicopter onto sea ice near the Barrow Arctic Research Center (BARC) building, where the third MAXDOAS instrument was located. Section 3 describes locations of the sites.

All MAX-DOAS instruments followed a scan pattern that included below-horizon viewing elevations through the zenith (nominally $-2,-1,0,1,2,3,5,10,20$, and $90^{\circ}$ elevation angles). Spectra were analyzed relative to the zenith spectrum in an elevation sequence to result in differential slant column densities, dSCDs, of $\mathrm{O}_{4}, \mathrm{BrO}, \mathrm{NO}_{2}$, and 
$\mathrm{O}_{3}$ as described in Peterson et al. (2015) with modifications described in the Supplement. At the negative elevation angles, the physical pathlength is shortened due to viewing the ground, causing a cutoff in the $\operatorname{dSCD}\left(\mathrm{O}_{4}\right)$ as compared to above-horizon spectra. For elevation scans when the near-horizon positive-elevation $\operatorname{dSCD}\left(\mathrm{O}_{4}\right)$ was greater than $2 \times 10^{43}$ molecule $^{2} \mathrm{~cm}^{-5}$, automated software determined the below-horizon half-cut elevation angle. Radiative transfer modeling with SCIATRAN (version 3.2.5) (Rozanov et al., 2005 ) indicated that this half-cut elevation angle was a function of instrument optical inlet height, occurring at $-0.1^{\circ}$ elevation for $3 \mathrm{~m}$ above ground level (a.g.l.) telescope height, which was appropriate to the IceLander platform, and $-0.3^{\circ}$ elevation for $14 \mathrm{~m}$ a.g.l. telescope height, which was appropriate for BARC building deployment. This optical measurement of the horizon elevation was then used to adjust the view elevations and resulted in shifts to the observation elevation of $< \pm 0.3^{\circ}$ from the nominal elevation. These corrected elevation angles were used in the subsequent analysis. All data are available from the NASA Earth Exchange (NEX) platform (https://nex.nasa.gov/nex/projects/1388/).

The dSCD measurements were inverted to vertical profiles of $\mathrm{BrO}$ mixing ratio and aerosol particle light extinction using the University of Heideleberg Profile (HeiPro) optimalestimation (OE) modeling software. HeiPro version 1.4 was used for retrieving aerosol optical properties, and HeiPro 1.3 was used for $\mathrm{BrO}$ trace gas analysis. All data were processed as hourly averages, resulting in vertical profiles from the surface to $4 \mathrm{~km}$. Only positive-elevation-angle (above-horizon) dSCD measurements were used in the OE modeling by selecting observations at elevations greater than the instrumental field of view $\left(0.7^{\circ} \mathrm{FWHM}\right)$. The aerosol grid consisted of 20 layers, each $0.2 \mathrm{~km}$ thick, and the $\mathrm{BrO}$ grid consisted of 40 layers, each $0.1 \mathrm{~km}$ thick.

As discussed in Peterson et al. (2015), and following the work of Payne et al. (2009), the full grid over-represents the true information content in the retrieved vertical profiles, which was typically $\sim 2-3$ degrees of freedom for signal (DOFS) for both $\mathrm{BrO}$ and aerosol extinction (see Fig. S1 in the Supplement). Therefore, the $\mathrm{BrO}$ amounts and vertical distributions were represented by two quantities: the lowertropospheric vertical column density (LT-VCD) and the fraction of that LT-VCD in the lowest $200 \mathrm{~m}\left(f_{200}\right)$. We refer to this representation of the data as "information-content-based retrievals". The BrO LT-VCD is nominally the integral of the vertical profile from the surface to the top of the model but loses sensitivity above about $2000 \mathrm{~m}$. The $f_{200}$ is the partial VCD from the surface to $200 \mathrm{~m}$ divided by the LT-VCD. For BrO retrieval, if either the DOFS in the lowest $200 \mathrm{~m}$ is $<0.7$ or the DOFS from 200 to $2000 \mathrm{~m}$ is $<0.5$, we do not report the data, ensuring that only retrievals that are well constrained by the observations are used. For some figures, we calculated the average $\mathrm{BrO}$ MR in the $0-200 \mathrm{~m}$ layer, repre-

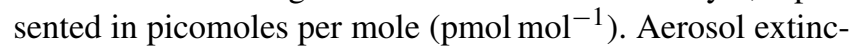
tion vertical profiles were retrieved by modeling $\operatorname{dSCD}\left(\mathrm{O}_{4}\right)$.
The aerosol extinction profiles were then integrated from the surface to $4 \mathrm{~km}$ to result in an aerosol optical depth (AOD, unitless), which was typically small for much of the campaign due to the predominance of clear skies. Larger AOD values were likely to be caused by clouds. Figure S1 shows reduction in the lofted information (DOFS for $\mathrm{BrO}$ in the 200-2000 ma.g.l. layer) at high AOD, which is consistent with Peterson et al. (2015).

\subsection{Ozone measurements}

Surface ozone mixing ratios were measured on each IceLander platform with a modified 2B Technologies Model 205 photometric ozone monitor (Halfacre et al., 2014). These instruments had a manufacturer-specified detection limit of ozone of $1.0 \mathrm{nmol} \mathrm{mol}^{-1}$. The surface ozone mixing ratio was measured in Barrow (Utqiagivik) (McClure-Begley et al., 2014) at the NOAA Global Monitoring Division (GMD) site $\left(71.3230^{\circ} \mathrm{N}, 156.6114^{\circ} \mathrm{W}\right), 2 \mathrm{~km}$ east of the BARC site.

\subsection{Meteorological measurements}

Barrow meteorological data were measured at the NOAA Barrow (Utqiagivik) airport (PABR) Automated Surface Observing System (ASOS) site $\left(71.286^{\circ} \mathrm{N}, 156.766^{\circ} \mathrm{W}\right)$, which is $5.5 \mathrm{~km} \mathrm{SW}$ from the BARC building. Winds were measured at $10 \mathrm{~m}$ a.g.l. using an ultrasonic anemometer, and temperature was measured at $2 \mathrm{~m}$ a.g.l. with an aspirated thermometer. Each IceLander platform carried cup anemometers for wind speed measurements that were recorded by data loggers (Campbell Scientific). The IceLander winds were recorded at approximately $2.5 \mathrm{~m}$ a.g.l..

\section{BROMEX field campaign and meteorological situation}

The BARC instrument was located at $71.325^{\circ} \mathrm{N}, 156.668^{\circ} \mathrm{W}$ and was used as a point of reference for the measurements at the IceLander sites, called IL1 and IL2. Initially, both IceLanders were co-located with BARC for intercomparison purposes. On the afternoon of March 8, IL2 was deployed $27 \mathrm{~km}$ west of BARC (to $71.2745^{\circ} \mathrm{N}, 157.295^{\circ} \mathrm{W}$ ), and on 9 March, IL1 was deployed $36 \mathrm{~km}$ east of BARC (to $71.355^{\circ} \mathrm{N}, 155.668^{\circ} \mathrm{W}$ ). At about 13:00 AKST on 23 March, the sea ice on which IL2 was located broke away from the landfast ice, and IL2 entered a drift phase for the remainder of the campaign. Figure 1 shows the locations of instrument packages overlaid on a map of the sea ice near local solar noon $(\sim 13: 30$ AKST $)$ on 23 March, and the animation in the Supplement shows the temporal evolution of sea ice and motion of the packages. IL1 was recovered from the sea ice via snowmobile near 12:00 AKST on 27 March and was operated co-located with the BARC instrument until 31 March. Following opening of the lead, IL2 drifted, reporting MAXDOAS data until it tipped over on 10 April. The locations of 

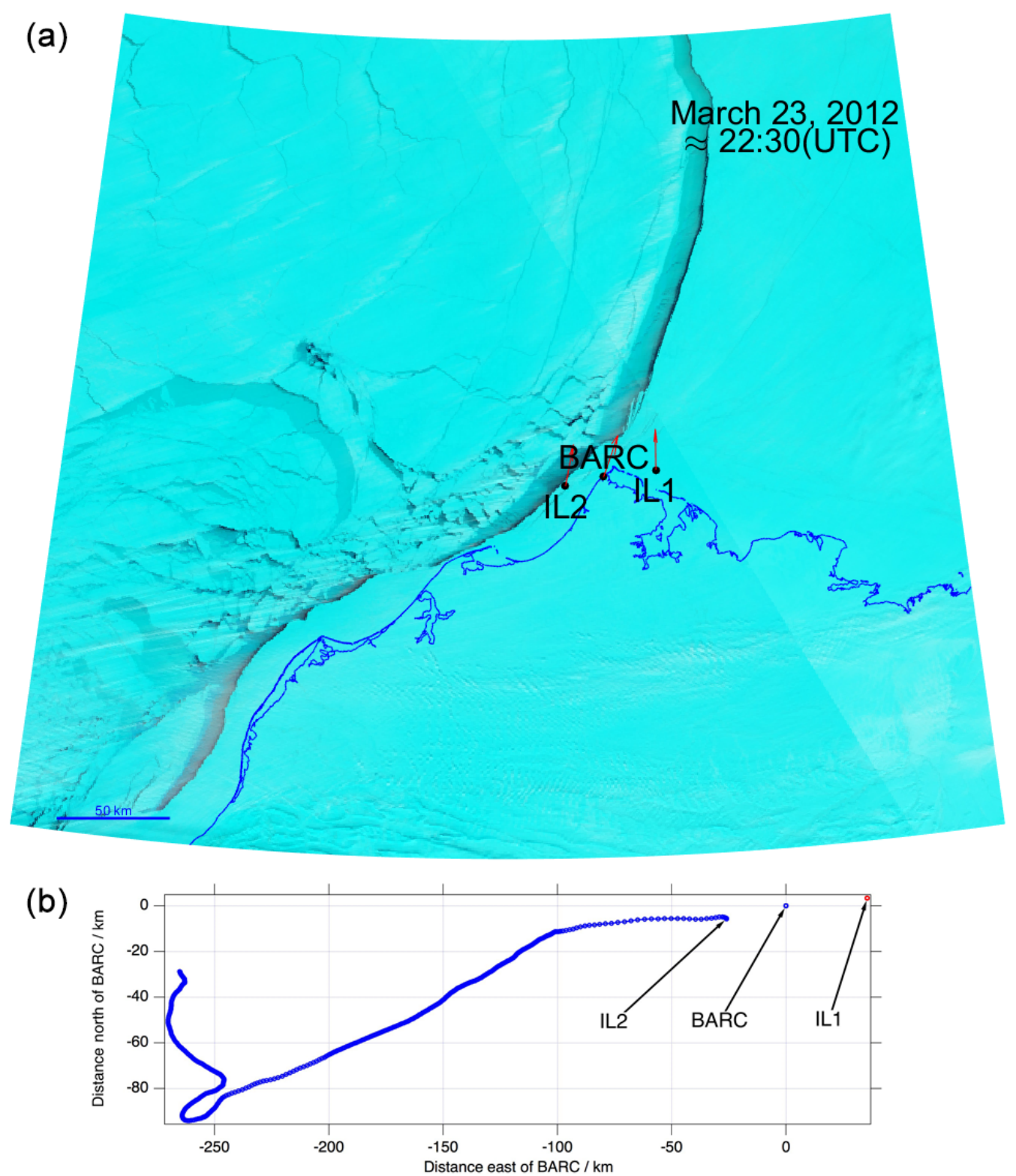

Figure 1. Panel (a) shows the locations of IL1, BARC, and IL2 instruments overlaid on the 23 March 2012 sea ice map from daily RGB composite 250m resolution MODIS images of ice conditions using bands 7, 2, and 1 (2105-2155, 841-876 and 620-670 nm wavelengths, respectively) from the NASA Aqua satellite. In this composite, sea ice is light blue, open water is black, and clouds are white. The red arrows show the MAX-DOAS viewing direction, over which BrO was averaged. The wind was from the northeast (can be seen by thin "cloud streets", which are wind-parallel horizontal convective rolls) and was pushing the lead open and causing IL2 to break away from shore-fast ice and drift westward. IL1 was the most upwind instrument, BARC in the middle, and IL2 downwind. Panel (b) shows the location of the two mobile platforms (IL1 and IL2) relative to BARC building during the drift phase. See Fig. 2 for drift distance versus time.

IL2 and IL1 compared to the BARC instrument location are shown in the lower panel of Fig. 1.

Figure 2 summarizes the meteorological conditions during the campaign. Temperatures were cold $\left(-15\right.$ to $\left.-35^{\circ} \mathrm{C}\right)$, but many days showed diurnal heating due to the returning sun of March/April. Surface wind speeds varied from calm to $12 \mathrm{~m} \mathrm{~s}^{-1}$ and were approximately $10 \mathrm{~m} \mathrm{~s}^{-1}$ at the time of ice break-off on 23 March. When wind speeds were low, shear was evident with higher winds at $10 \mathrm{~m}$ a.g.l. (measured at the Barrow airport site) but less wind speed closer to the surface at the $2.5 \mathrm{~m}$ a.g.l. IL sites. Two periods (28 March-2 April and 6-8 April) of zero reported wind speed at IL2 were likely caused by icing of the cup anemometer at that site and are probably artifacts.

The wind direction in this period was bimodal with a predominant wind from the north-through-east sector and a sec- 


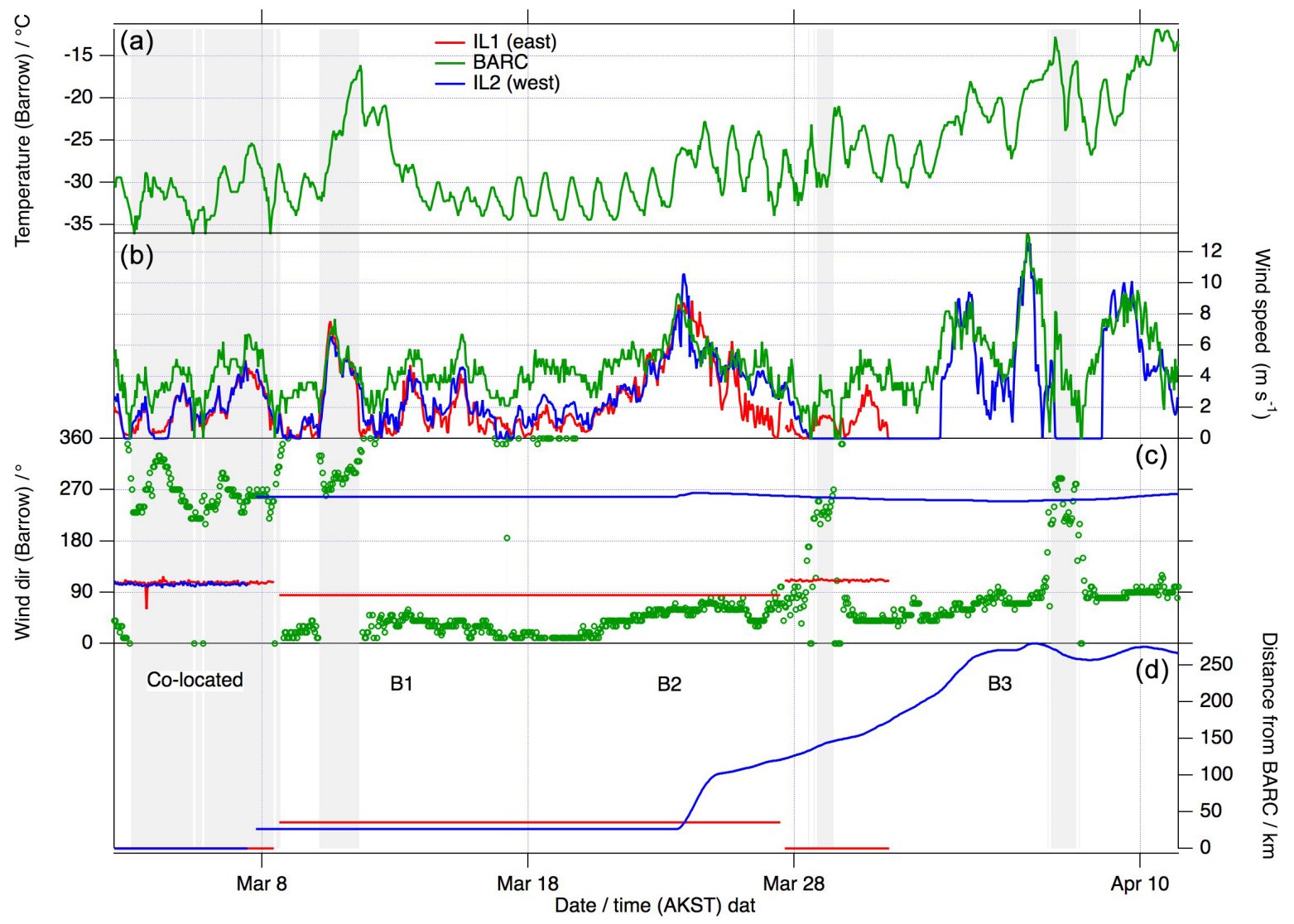

Figure 2. Meteorological data from the BROMEX campaign and drift information of IL1 and IL2. Panel (a) shows Barrow (Utqiagivik) temperature (2 m a.g.l.) measured at the NWS-AWOS site. Panel (b) shows wind speed at all three sites, but the Barrow winds were measured at $10 \mathrm{~m}$ a.g.1., while IL1 and IL2 were measured at $2.5 \mathrm{~m}$ a.g.1. Panel (c) shows wind direction at Barrow (Utqiagivik, green circles) and in blue and red lines the direction of the IL platforms from the BARC building. The wind direction was bimodal (Fig. S2); west winds are plotted with a shaded background, and east winds without shading. Panel (d) shows the distance of the IL platforms from BARC. Both IL platforms started at BARC and were deployed on 8 and 9 March. On 23 March, IL2's sea ice broke away from the land, starting its drift phase; on 27 March, IL1 returned to BARC.

ondary wind peak from the west (see wind direction histograms in Fig. S2). We divided the campaign into periods of "east" wind and "west" wind by taking the sector from 160 to $340^{\circ}$ as "west" and from 340 through 0 to $160^{\circ}$ as "east". The predominant "east" wind was from the northeast (average direction: $48^{\circ}$; standard deviation: $29^{\circ}$ ), and the lessfrequent "west" wind was from the west (average direction $262^{\circ}$; standard deviation: $34^{\circ}$ ). The design of the experiment was to have one IL platform upwind and one downwind of BARC, and this design often worked, as evident by the wind direction being relatively parallel to the ENE-WSW direction of the IL1-BARC-IL2 line of sites. For the majority of the deployment phase, IL1 was upwind of BARC, and IL2 was downwind. The lowest panel of Fig. 2 shows the distance of the IL platforms from BARC. IL1 never moved significantly, but IL2's drift brought it $\sim 250 \mathrm{~km}$ west, typically downwind, from BARC. IceLander 2 MAX-DOAS observations stopped on 10 April at 17:30 AKST, when IL2 tipped $33^{\circ}$, preventing its optical scanner from observing the horizon.

For this analysis, we divided the campaign into four periods:

- intercomparison: 2-8 March, in which all instruments were compared at BARC;

- period B1: 8-18 March, which had no open leads and during which the array was deployed;

- period B2: 18-28 March, which covered the lead opening event when IL2 drifted west;

- period B3: 28 March-10 April, during which time IL1 was returned to BARC and shut down and IL2 continued observing until tipped. 

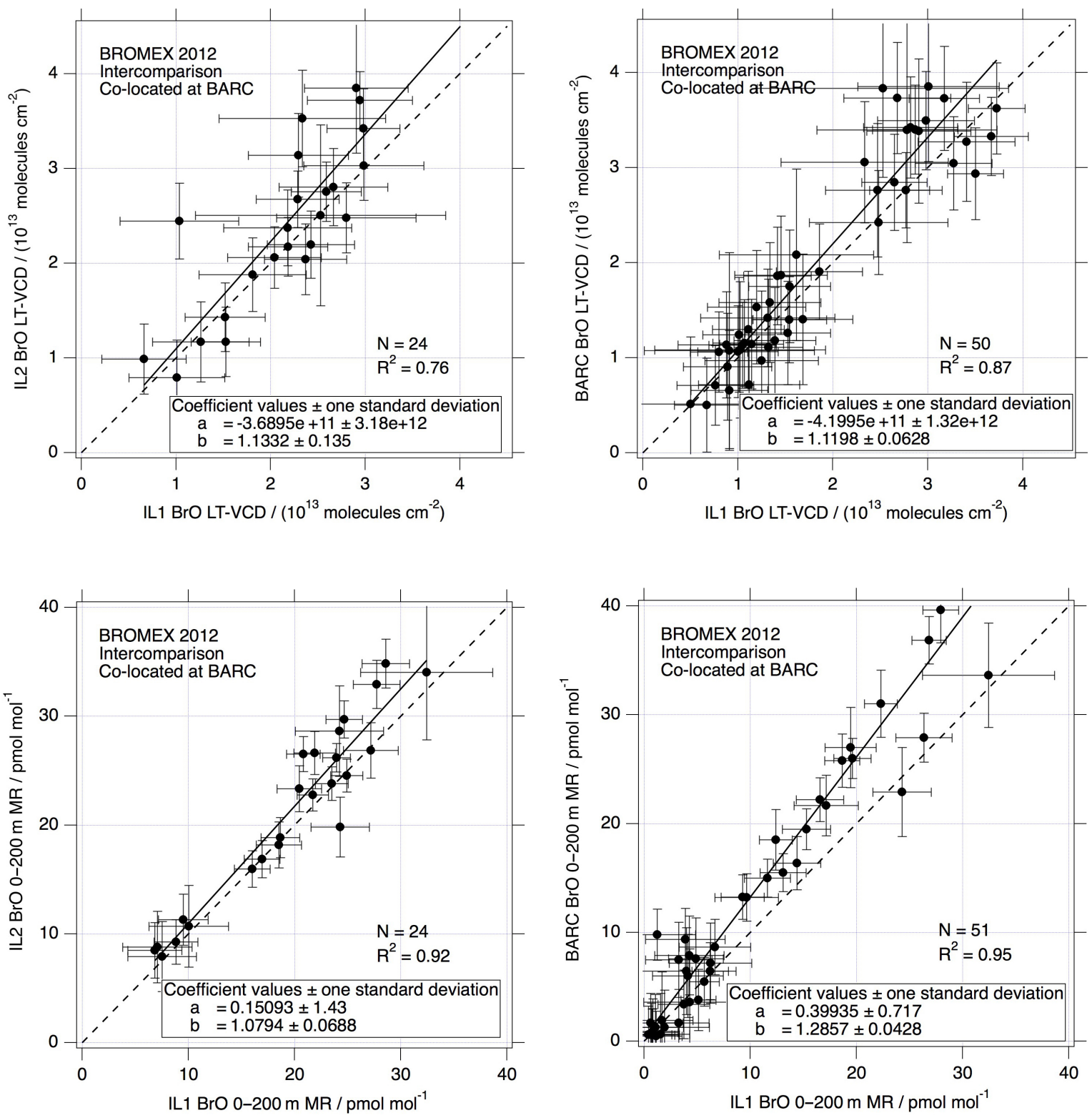

Figure 3. Intercomparison of BrO measurements between BARC, IL1, and IL2 when all instruments were co-located at BARC. Error bars $(1 \sigma)$ are shown on each data point and were typically around $5 \times 10^{12}$ molecule cm $^{-2}$ for BrO LT-VCD and $3 \mathrm{pmol} \mathrm{mol}^{-1}$ for the BrO 0-200 $\mathrm{m}$ mixing ratio (MR).

\section{Results}

\subsection{Intercomparison of MAX-DOAS observations when co-located}

To assure intercomparability of the MAX-DOAS measurements, all hours when the IceLander instruments were at BARC were correlated. This selection led to $24 \mathrm{~h}$ of IL2-IL1 comparison and $\sim 50 \mathrm{~h}$ of BARC-IL1 comparison. Because IL1 was recovered, pre- and post-deployment intercomparison data were determined, but IL2 was lost, so only predeployment intercomparison was possible. Figure 3 shows the results of these comparisons. For the $\mathrm{BrO} 0-200 \mathrm{~m}$ mixing ratio, we found high $R^{2}$ correlations between instruments of 0.92 and 0.95 , intercepts $<0.5 \mathrm{pmol} \mathrm{mol}^{-1}$, and slopes of 1.08 and 1.29. Typical errors $(1 \sigma)$ for the $\mathrm{BrO}$ surface mixing ratio were $2-3 \mathrm{pmol} \mathrm{mol}^{-1}$. For the BrO LT-VCD, $R^{2}$ correlations were 0.76 and 0.87 with intercept statistics within $1 \sigma$ of zero and slope within $2 \sigma$ of unity. Typical BrO LT-VCD errors $(1 \sigma)$ were $\sim 5 \times 10^{12}$ molecule $\mathrm{cm}^{-2}$. These results demonstrate good agreement between three independent instruments and allow us to use the instruments to determine horizontal gradients. 


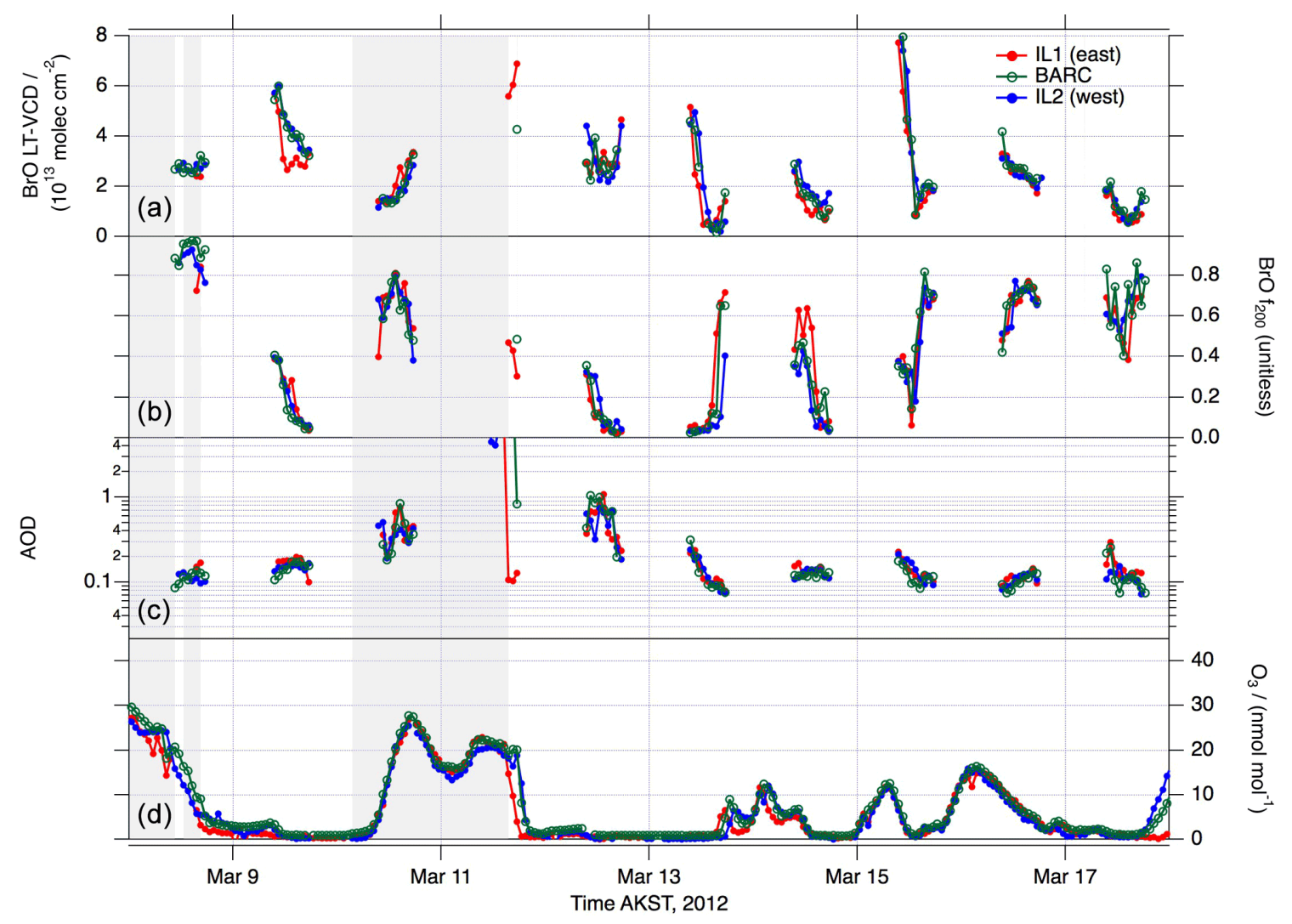

Figure 4. Hourly BrO, aerosol optical depth (AOD), and ozone $\left(\mathrm{O}_{3}\right)$ data from each of the three sites (IL1, BARC, IL2) during period B1. Panel (a) shows the lower-tropospheric VCD of BrO (integrated concentration from surface to top of model). Panel (b) shows the fraction of BrO LT-VCD in the lowest $200 \mathrm{~m} ; f_{200}=\mathrm{VCD}(0-200 \mathrm{~m}) /$ LT-VCD. Panel (c) shows the vertical integral of the aerosol extinction from 0 to $4000 \mathrm{~m}$ (the AOD). Panel (d) shows the in situ surface ozone mixing ratio measured on the IL platforms and as measured by NOAA-GMD $\sim 2 \mathrm{~km}$ northeast of the BARC building.

\subsection{Gradient observations during phases B1-B3}

Figures 4-6 show atmospheric chemical observations during these three phases. During this campaign, there was a great deal of variability of $\mathrm{BrO}$ by all measures. The LT-VCD varied $\sim 0$ to $\sim 8 \times 10^{13}$ molecule $\mathrm{cm}^{-2}$, and the fraction in the lowest $200 \mathrm{~m}\left(f_{200}\right)$ varied the full possible range: 0 to 1 . Generally, period B3 had lower $f_{200}$ values, and period B2 lacked very high column events.

During period $\mathrm{B} 1, \mathrm{BrO}$ at the three sites followed the same behavior. Large changes such as the precipitous drop in BrO LT-VCD from $>6 \times 10^{13}$ molecule $\mathrm{cm}^{-2}$ on 15 March at sunrise down to near-zero values in the late morning happened at all three sites. This change appeared to be at least partially due to low-ozone-induced $\mathrm{BrO}_{x}$ repartitioning at the surface, as discussed in Sect. 5.3. Decreasing AOD was also observed at this time, which was probably the result of an air mass change (e.g., frontal passage). The vertical structure $\left(f_{200}\right)$ also agreed very well between sites. There were some time shifts of up to $\sim 2 \mathrm{~h}$ between sites, which was consistent with the corresponding transport time, but the sites generally followed the same pattern even if they were shifted in time by an hour or two.

Period B2 started with consistent meteorology from period B1, although the wind increased from 18 March up until the ice break-off event on 23 March. The BrO LT-VCD during this period was lower than its peak earlier in the campaign, and very shallow (e.g., $f_{200}>0.5$ ) events were observed. The association of shallow BrO layers with small column density was noted by Peterson et al. (2015) and was interpreted as a result of poor vertical mixing preventing propagation of surface-based $\mathrm{BrO}$ aloft. During the static phase (prior to ice break-off and IL2 motion) of the study (8 to 23 March), correlations between $\mathrm{BrO}$ measurements at BARC and IL2 compared to IL1 were still high despite horizontal separation (see Fig. S3). The BARC-IL1 LT-VCD correlation $R^{2}$ value was 0.84 , and the IL2-IL1 correlation was $R^{2}=0.79$. The surface $\mathrm{BrO}$ mixing ratios were similarly correlated, with $R^{2}$ values of 0.85 and 0.81 , respectively. These correlation coefficients were similar to the co-located period, despite separation between sites of $36 \mathrm{~km}$ (BARC-IL1) and $63 \mathrm{~km}$ (IL2-IL1). Figure S4 shows histograms of LT-VCD differences between sites. This analysis shows that the probabil- 


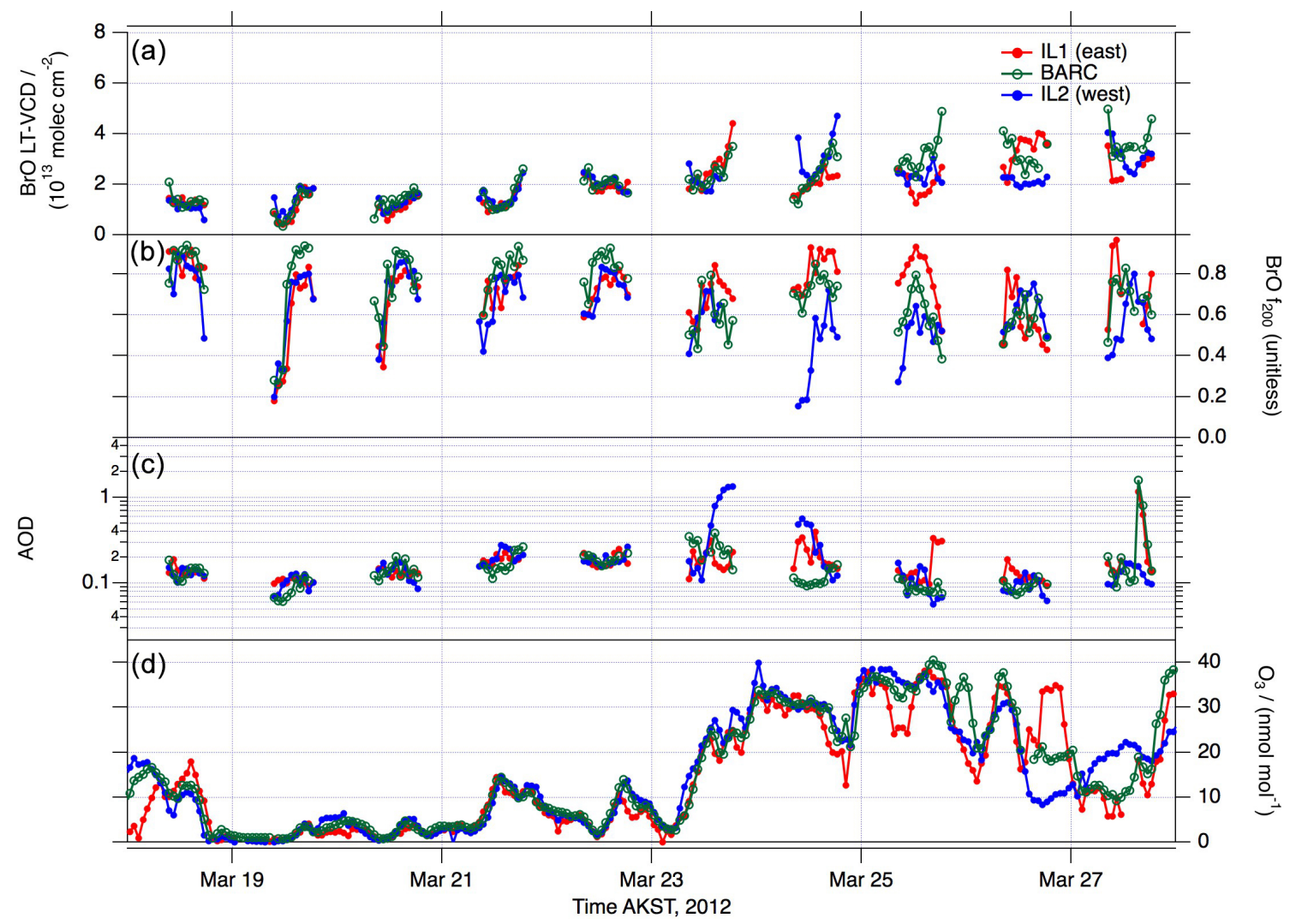

Figure 5. The same as in Fig. 4 but for period B2. IL2 began drifting away from BARC on 23 March.

ity of having a difference with an absolute value less than $10^{13}$ molecule $\mathrm{cm}^{-2}$ ( $2 \sigma$ of the BrO LT-VCD measurement error) is $87 \%$ for IL1-IL2 and $83 \%$ for IL1-BARC, again indicating that, at most times without open sea ice leads, strong spatial gradients in $\mathrm{BrO}$ are not observed.

Figures 4 and 5 also demonstrate that ozone at the three locations was highly correlated before the lead opening event on 23 March. Generally, before lead opening, surface ozone mixing ratios were low $\left(<\sim 15 \mathrm{nmol} \mathrm{mol}^{-1}\right)$, but when the wind speed increased (10 and 11 March, and surrounding the lead opening on 23 March), ozone mixing ratios increased, consistent with ozone downward transport associated with wind-induced mixing (Jacobi et al., 2010). We also observed reduced wind shear between the Barrow measurements (at $10 \mathrm{~m}$ a.g.1.) and the IL platforms (2.5 m a.g.1.) during the higher-wind periods, consistent with reduced stratification of air near the surface.

Upon lead opening on the afternoon of 23 March, changes to the vertical structure of $\mathrm{BrO}$ appeared. The most downwind site, IL2, was within a surface-based cloud formed by the open lead, and the AOD increased significantly at that location as compared to the other sites. This cloud precluded BrO observations at IL2 until the next day (24 March), on which a gradient in $f_{200}$ developed between IL1 (upwind), BARC (middle), and IL2 (downwind), with a shallower BrO distribution (higher $f_{200}$ values) at the upwind site and a more vertically mixed behavior (lower $f_{200}$ values) at IL2. Note that the surface ozone mixing ratio was high enough (more than a few nanomoles per mole) that repartitioning of $\mathrm{BrO}_{x}$ at the surface was not responsible for these lower $f_{200}$ values at IL2. This gradient in $\mathrm{BrO}$ vertical structure persisted until the morning on $26 \mathrm{March}$, when the three sites appeared to be in different air masses (as indicated by different ozone mixing ratios at the three sites, in contrast to their prior highly correlated behavior). This change in ozone at Barrow (BARC) on 26 March was noted by Moore et al. (2014) as a reduction in vertical mixing due to re-freezing of previously open leads upwind of BARC.

On the afternoon of 27 March, IL1 was recovered and resumed operation at BARC. During this post-deployment co-location period, IL1 and BARC agreed well (Fig. 6). On 28 March (Fig. 6), there was a different vertical profile at IL2 than at BARC, with a surface-based event on the sea ice at IL2 that had higher $f_{200}$ values than BARC. During the downwind drift period (B3), the highly correlated behavior observed prior to lead opening on 23 March was replaced with notable discrepancy between IL2 and BARC. However, the daily-timescale values of all quantities vary similarly between these sites despite the large distance ( $\sim 130$ to $260 \mathrm{~km})$ between sites. 


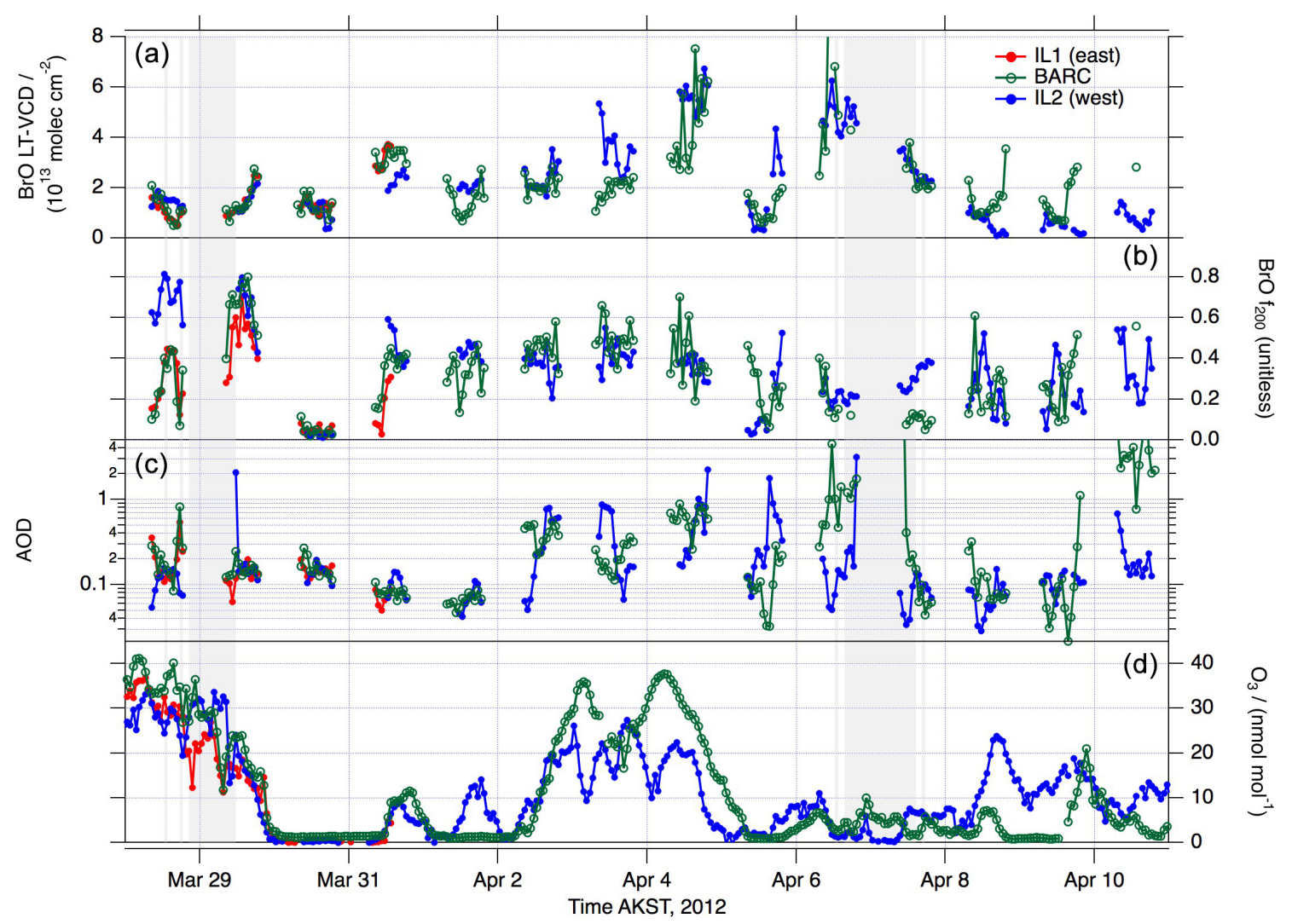

Figure 6. The same as in Fig. 4 but for period B3. IL1 was recovered to BARC on 27 March, was co-located with the BARC instrument during this period, and was shut down at the end of March.

\subsection{Selected cases}

Figure 7 shows altitude-time profiles of aerosol extinction and $\mathrm{BrO}$ mixing ratio on the selected days of $9,15,16$, and 22-24 March. These cases were selected to have similar meteorological conditions, with winds from the northeast, moderate to low AOD (except for around the lead opening event, particularly at IL2, on the afternoon of $23 \mathrm{March}$ ), and cold temperatures $\left(-25\right.$ to $\left.-35^{\circ} \mathrm{C}\right)$. There was generally good agreement between the three sites, in agreement with the information-content-based analysis shown in Figs. 4-6. These altitude-time profile presentations are informative despite the fact that they over-represent the vertical information, particularly aloft, where the averaging kernels show that the vertical resolution is broadened significantly (Frieß et al., 2011; Peterson et al., 2015). It is likely that some subtle differences aloft are simply due to lack of vertical resolution, but the consistent features between sites are likely well represented in these profile plots.

\subsubsection{March}

This case shows a vertically thick surface-based aerosol layer, with $\log _{10}$ (extinction) $>-1$ up to $\sim 1 \mathrm{~km}$. During this day, surface ozone was sufficiently low $\left(<1 \mathrm{nmol} \mathrm{mol}^{-1}\right)$ af- ter noon to cause $\mathrm{BrO}_{x}$ repartitioning at the surface, which is evident by reduced values of $f_{200}<0.1$ (Fig. 4). The time profile plots show that $\mathrm{BrO}$ was not present at the surface, but the peak mixing ratio moved aloft. There was a moderate decay in the LT-VCD on this day, but the occurrence of surface $\mathrm{BrO}_{x}$ repartitioning did not eliminate $\mathrm{BrO}$ aloft.

\subsubsection{March}

This day had dramatic BrO changes with nearly temporally coordinated behavior at all three sites. Figure 4 shows that in the morning there was high BrO LT-VCD $(>7 \times$ $10^{13}$ molecule $\mathrm{cm}^{-2}$ ), which declined to near-zero values $\left(<1 \times 10^{13}\right.$ molecule $\left.\mathrm{cm}^{-2}\right)$ at noon and then recovered moderately $\left(\sim 2 \times 10^{13}\right.$ molecule $\left.\mathrm{cm}^{-2}\right)$. The morning vertical distribution of $\mathrm{BrO}$ showed $f_{200}=0.3$, which decreased to lower values, consistent with surface-based $\mathrm{BrO}_{x}$ repartitioning at low ozone levels, and then $f_{200}$ increased again to $>0.5$ late in the afternoon, indicating a surface-based $\mathrm{BrO}$ layer. The BrO profiles (Fig. 7) show a relatively thick BrO layer (to $1 \mathrm{~km}$ ) in the morning that decayed to zero at noon and then built a shallow event in the afternoon. Aerosol extinction on this day was at relatively high values in the morning but decreased to low levels $(\log$ (extinction) $<-1.2$ ), particularly above the first $200 \mathrm{~m}$ a.g.l., in the afternoon. 
(a)

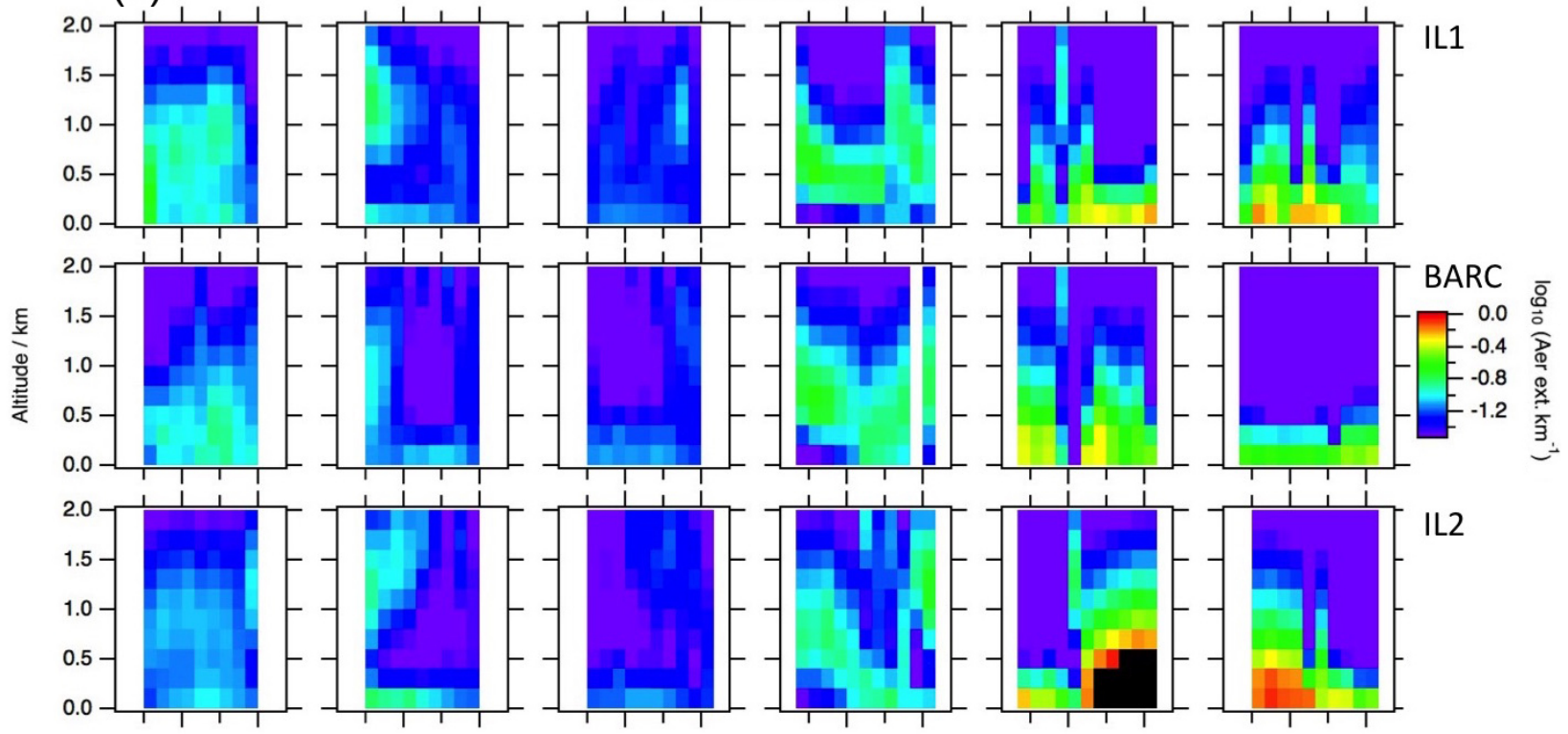

(b)

BrO mixing ratio

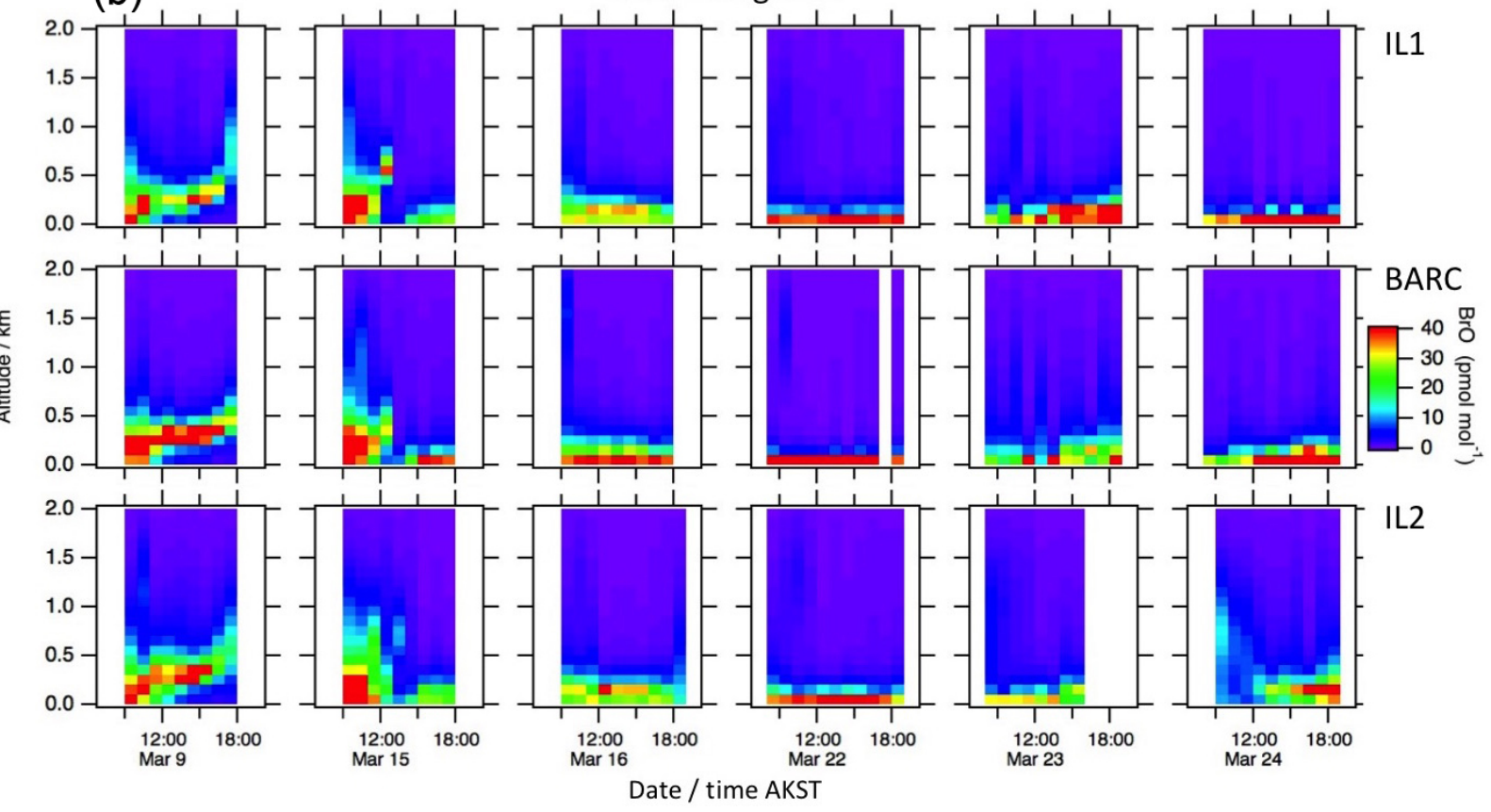

Figure 7. Altitude-time profiles of aerosol particle extinction (a) and $\mathrm{BrO}$ mixing ratio (b) on selected days during BROMEX in 2012. Ticks on the time axis occur every $3 \mathrm{~h}$. Black pixels indicate extinction above $1 \mathrm{~km}^{-1}$, which may be too optically thick to be reliably calculated via the optimal-estimation analysis and probably make higher-altitude measurements at that time unreliable as well. BrO mixing ratios above $40 \mathrm{pmol} \mathrm{mol}^{-1}$ are shown as black and are most likely artifacts of the limited vertical resolution of the optimal-estimation analysis. White periods indicate missing data by lack of sun, instrumental problems, or low visibility (e.g., afternoon of 23 March at IL2 due to the lead opening event).

\subsubsection{March}

This day had a shallow surface-based $\mathrm{BrO}$ event with $f_{200}$ values between 0.4 and 0.8 . Sufficient ozone was present at the surface to prevent repartitioning of $\mathrm{BrO}_{x}$. The aerosol profiles show that there was very little aerosol extinction aloft and that there were only small amounts in the lowest few hundred meters. Figure 7 shows some evidence of a lofted aerosol particle layer, but that layer was decoupled from the 
surface aerosol layer and was not associated with $\mathrm{BrO}$ enhancements.

\subsubsection{March}

This case, which was the day before the lead opening event, shows an interesting contrast to 16 March. There was again a surface-based $\mathrm{BrO}$ event, with $f_{200}>0.6$, which was slightly shallower than on 16 March. However, the aerosol extinction was both higher in magnitude and distributed much more aloft on this date than on 16 March. Figure 7 demonstrates that the aerosol layer descended throughout the day and seemed to be overlapping the surface layer. However, despite the presence of aerosol particles aloft, Fig. 7 shows that $\mathrm{BrO}$ does not appear aloft (as it had on 9 and 15 March in the morning), as discussed in Sect. 5.4.

\subsubsection{March}

This was the day of the lead opening event. All three sites began with a shallow $\mathrm{BrO}$ event in the morning. There was moderate aerosol extinction, mostly based at the surface but extending aloft. At the time of the lead opening event, the aerosol extinction at IL2 (downwind) went high, $>1 \mathrm{~km}^{-1}$, in the lowest $400-600 \mathrm{~m}$ a.g.l., consistent with that instrument being within the convective lead cloud. Unfortunately, the lead cloud prevented BrO LT-VCD or $f_{200}$ from being observed at IL2, but observations become valid at all three sites on the next day.

\subsubsection{March}

This case shows the next-day response of $\mathrm{BrO}$ to this lead opening event. Downwind of the open and re-freezing lead, IL2 observed a decrease in $\mathrm{BrO}$ mixing ratio at the surface (Fig. 7) and a broadening of the $\mathrm{BrO}$ vertical profile to greater heights. Unlike most times earlier in the campaign, $\mathrm{BrO}$ and aerosol extinction (Fig. 7) show spatial gradients between the sites, as was discussed using BrO LT-VCD and $f_{200}$ earlier in this section. The downwind IL2 site had high aerosol extinction in a thick $(>400 \mathrm{~m}$ ) surface based layer, which decayed in the afternoon. Ozone was high $\left(\sim 30 \mathrm{nmol} \mathrm{mol}^{-1}\right)$ at all sites, eliminating $\mathrm{BrO}_{x}$ repartitioning as a cause for this difference.

\section{Discussion}

\subsection{BrO measurements were highly correlated on $\sim 30 \mathrm{~km}$ length scales in the absence of leads}

During the pre-lead-opening period (before 23 March), Figs. 4 and 5 show that measurements at the three sites correlate despite physical separation between sites of $\sim 30 \mathrm{~km}$, and even $\sim 60 \mathrm{~km}$ from IL2 to IL1. The correlation (Fig. S3) and $R^{2}$ values of these separated measurements in this pe- riod are quite similar to the times when the instruments were co-located at BARC (Fig. 3). It is evident from examination of the time series data (Figs. 4 and 5) that some changes in BrO occurred at one site before another, with temporal shifts of a couple hours. This type of temporal shift would have decreased the hourly correlation coefficient and was likely responsible for some of the reduction of $R^{2}$ between $\mathrm{BrO}$ column densities for the deployed site locations and the colocated sites. The high correlation of measurements separated by length scales similar to satellite pixel dimensions (Richter et al., 1998; Wagner and Platt, 1998; Begoin et al., 2010; Choi et al., 2012; Sihler et al., 2012) is an important finding that generally indicates that satellite-based $\mathrm{BrO}$ observations are likely to represent horizontal spatial features effectively. Variability of $\mathrm{BrO}$ in the stratosphere (Theys et al., 2009; Salawitch et al., 2010) or free troposphere (Theys et al., 2011; Choi et al., 2012) could affect this conclusion, but one would expect less horizontal inhomogeneity aloft because of a lack of small-scale features such as leads or topography, which are only present at ground level. Although we observe that the general behavior of $\mathrm{BrO}$ is high correlation despite spatial separation, transport events that have gradients significantly sharper than satellite length scales are clearly evident in the data. For example, on 13 March, Fig. 4 shows time-staggered changes in BrO LT-VCD and $f_{200}$. Peterson et al. (2017) used airborne DOAS to study the 13 March case and observed a very steep BrO gradient that transports with the wind, clearly indicating that features on the edges of air masses are $<30 \mathrm{~km}$. Therefore, we interpret the $\mathrm{BrO}$ distribution as being large regions of relatively consistent $\mathrm{BrO}$ on $>30 \mathrm{~km}$ length scales with sharp contrasts at their edges that are much smaller than satellite length scales.

\subsection{Snowpack-based BrO events were common during BROMEX}

Many of the BrO events that occurred during BROMEX were ground-based with a high fraction of the BrO LT-VCD in the lowest $200 \mathrm{~m}$ (large $f_{200}$ ). Peterson et al. (2015) showed that shallow events are associated with stable meteorological conditions, which predominated during much of this campaign, particularly before the lead opening event. These shallow events are consistent with a snowpack source of reactive bromine (Simpson et al., 2007a; Pratt et al., 2013). Reactive bromine is relatively short lived due to termination reactions, which often lead to $\mathrm{HBr}$ or $\mathrm{HOBr}$ bromide reservoirs (Platt and Hönninger, 2003). However, these reservoir species can recycle to reactive halogens through heterogeneous chemical reactions. Fan and Jacob (1992) proposed that heterogeneous Reaction (R3) on aerosol surfaces was a critical step for recycling reactive bromine and activating particle-bound bromide $\left(\mathrm{Br}^{-}\right)$to reactive bromine after photolysis of $\mathrm{Br}_{2}$.

$\mathrm{HOBr}+\mathrm{H}^{+}+\mathrm{Br}^{-} \rightarrow \mathrm{Br}_{2}+\mathrm{H}_{2} \mathrm{O}$ 
Subsequent laboratory studies have demonstrated that Reaction (R3) is efficient on saline liquid, ice, and aerosol particle surfaces (Fickert et al., 1999; Huff and Abbatt, 2000, 2002; Wachsmuth et al., 2002; Abbatt et al., 2012; Wren et al., 2013; Roberts et al., 2014). Other mechanisms of halogen activation also exist, such as the reaction of ozone with aerosol or ice-bound bromide (Oum et al., 1998; Hunt et al., 2004), but these processes are typically slower than photochemical bromine release. Because heterogeneous chemistry is required for reactive bromine recycling, we interpret these surface-based events as recycling reactive bromine on snowpack surfaces.

As evident from the case studies on 16 and 22 March, shallow surface-based $\mathrm{BrO}$ events can have different relationships to aerosol vertical structures. On 16 March, there was little aerosol extinction aloft, implying low aerosol surface area density, which would have slowed heterogeneous recycling on lofted aerosol particles. One might interpret the lack of aerosol particles aloft as causing the event to be surface based. However, on 22 March, there was significantly more aerosol extinction detected aloft, but the event remained based at the surface. Potential reasons for $\mathrm{BrO}$ not being observed aloft on 22 March despite the presence of aerosol particles could be a lack of vertical mixing due to meteorological inversions (Peterson et al., 2015), which were common during the campaign. Specifically, on 22 March, the meteorological sounding balloon launched from Barrow (Utqiagivik) at 15:00 AKST showed an inversion with $\mathrm{d} T / \mathrm{d} z$ of $+15 \mathrm{~K} \mathrm{~km}^{-1}$ in the lowest $200 \mathrm{~m}$ a.g.l.. An alternative hypothesis for the lack of reactivity on the lofted aerosol on this date could be that the particles had a chemical composition that was not conducive to halogen release. For example, if the particles had not contained bromide $\left(\mathrm{Br}^{-}\right)$, Reaction (R3) would not have occurred. Laboratory (Fickert et al., 1999; Huff and Abbatt, 2002; Abbatt et al., 2012; Wren et al., 2013; Roberts et al., 2014) and field (Pratt et al., 2013) studies indicate that acidic $\mathrm{pH}$ is also required for Reaction (R3), adding another potential reason. Another alternative could be that the aerosol size distribution consists of larger particles for which diffusion limits gas-surface reaction rates or that these particles are long-range-transported Arctic haze particles (Quinn et al., 2002).

\subsection{Low-ozone-induced BrOx repartitioning affected BrO vertical profiles}

Past considerations of reactive bromine chemistry has indicated that $\mathrm{BrO}_{x}$ partitioning between $\mathrm{Br}$ atoms and $\mathrm{BrO}$ can be an important control on $\mathrm{BrO}$ abundance, which has been modeled (Sander et al., 1997; Evans, 2003; Toyota et al., 2014) and observed (Simpson et al., 2007a; Helmig et al., 2012). The low ozone mixing ratios observed here (often $<1-2 \mathrm{nmol} \mathrm{mol}^{-1}$ ) controlled surface $\mathrm{BrO}_{x}$ partitioning and reduced $\mathrm{BrO}$ abundance, and thus affected the vertical distribution of $\mathrm{BrO}$. Low $\mathrm{BrO}$ concentrations would also have reduced the formation of $\mathrm{HOBr}$, which is necessary for "bromine explosion" events (Wennberg, 1999; Lehrer et al., 2004) that recycle $\mathrm{BrO}_{x}$ via Reaction (R3). Through reduced heterogeneous recycling, $\mathrm{BrO}_{x}$ would have decayed over time as termination reactions (e.g., $\mathrm{Br}+\mathrm{H}_{2} \mathrm{CO}$ ) occurred. On 9 March, ozone levels began the day above this threshold but soon decayed below the threshold, and $\mathrm{BrO}$ at the surface decayed to zero (Fig. 7). This repartitioning effect reduces the $f_{200}$ value to $<0.1$ (Fig. 4), and $\mathrm{BrO}$ exists only aloft in the afternoon (Fig. 7). On 9 March, the reactive bromine aloft was apparently generated at the surface and moved aloft, where it recycled on aerosol particle surfaces.

On 15 March, low ozone values were observed, and what was a very intense $\mathrm{BrO}$ event in the morning decayed to nearzero LT-VCD at noon. At noon, the vertical structure of $\mathrm{BrO}$ became lofted ( $f_{200}<0.1$; Fig. 4$)$, but aerosol extinction aloft was smaller (Fig. 7; see Sect. 5.4) and BrO did not propagate aloft after noon (Fig. 7). Interestingly, on 15 March, a shallow $\left(f_{200}>0.5\right)$ post-noon $\mathrm{BrO}$ column appeared (Fig. 7), potentially enabled by decreased afternoon photolysis rates and an increase in $\mathrm{O}_{3}$ in the late afternoon that repartitioned $\mathrm{BrO}_{x}$ back towards $\mathrm{BrO}$.

$\mathrm{BrO}_{x}$ repartitioning may also have been responsible for low surface BrO levels and low $f_{200}$ values on many of the days during this campaign. Peterson et al. (2016) found that this period (spring 2012) had particularly low surface ozone, and Oltmans et al. (2012) showed that March ozone depletion event (surface $\mathrm{O}_{3}<10 \mathrm{nmol} \mathrm{mol}^{-1}$ ) probability has been increasing over the 38-year period from 1972 to 2010. Therefore, the prevalence of $\mathrm{BrO}_{x}$ repartitioning in the BROMEX data set may not be representative of average behavior and warrants further climatological investigation through analysis of larger data sets.

\subsection{Aerosol extinction aloft was necessary but not sufficient for BrO to be present aloft}

The cases presented in Sect. 4.3 and discussed above found that shallow $\mathrm{BrO}$ events sometimes occurred with little aerosol aloft (16 March) and at other times with significantly more aerosol aloft (22 March). When $\mathrm{BrO}_{x}$ repartitioning affected surface $\mathrm{BrO}$, sometimes the $\mathrm{BrO}$ event migrated aloft in the presence of significant aerosol loading (9 March), but sometimes $\mathrm{BrO}$ decayed both at the surface and aloft (15 March). In all of these cases, $\mathrm{BrO}$ only propagated aloft into layers with $\log _{10}$ (aerosol extinction) $>\sim-1$, meaning aerosol extinction coefficient $\left(k_{\text {ext }}\right)>\sim 0.1 \mathrm{~km}^{-1}$.

To check if this aerosol extinction coefficient threshold is reasonable, we can use the observation to estimate heterogeneous chemical rates. We encourage future photochemical modeling to answer this question more fully. Aerosol extinction is related to aerosol surface area density by $k_{\text {ext }}=Q_{\text {ext }} \times \mathrm{SA} / 4$, where $Q_{\text {ext }}$ is the extinction efficiency, which maximizes for submicron particles at a value close to 4 , and SA is the surface area density. Assuming 
maximal $Q_{\text {ext }}=4$ gives the minimum surface area density $\left(\mathrm{SA}=\sim 100 \mu \mathrm{m}^{2} \mathrm{~cm}^{-3}\right.$ ) that is consistent with the observed threshold $k_{\text {ext }}=\sim 0.1 \mathrm{~km}^{-1}$, which appears necessary for $\mathrm{BrO}$ to propagate aloft. In the absence of diffusion limitations (e.g., typically for submicron particles), the rate of a heterogeneous reaction is $k_{\text {het }}=1 / 4 c \gamma \mathrm{SA}$, where $c$ is the average velocity of the gas, and $\gamma$ is the reaction probability. Wachsmuth et al. (2002) indicate that heterogeneous uptake of $\mathrm{HOBr}$ on sea salt aerosol particles is limited by accommodation and has the value $\gamma=0.6$. The actual value of $\gamma$ may be lower because ambient particles are likely not solely sea salt. At $100 \mu \mathrm{m}^{2} \mathrm{~cm}^{-3}$ and thermal velocity of $\mathrm{HOBr}$ at $253 \mathrm{~K}\left(-20^{\circ} \mathrm{C}\right), c=255 \mathrm{~m} \mathrm{~s}^{-1}$, and thus $k_{\text {het }}=0.0038 \mathrm{~s}^{-1}$, corresponding to an $\sim 4 \mathrm{~min} \mathrm{HOBr}$ lifetime. Thompson et al. (2015) indicate the photolysis rate $J(\mathrm{HOBr})=0.0023 \mathrm{~s}^{-1}$ for springtime Barrow (Utqiagivik) conditions, so this surface area density results in a heterogeneous reactivity rate that competes with $\mathrm{HOBr}$ photolysis. Photolysis of $\mathrm{HOBr}$ cycles reactive bromine and destroys ozone but does not increase the reactive bromine pool. On the other hand, Reaction (R3) forms $\mathrm{Br}_{2}$, and upon $\mathrm{Br}_{2}$ photolysis results in two reactive bromine species from the one $\mathrm{BrO}$ radical that formed HOBr (Wennberg, 1999; Platt and Hönninger, 2003). Thus, for bromine to "explode", heterogeneous reactions must occur fast enough to compensate for reactive bromine losses (e.g., termination reactions such as $\mathrm{Br}+\mathrm{H}_{2} \mathrm{CO}$ ). The observational threshold found in this study appears to be sufficiently high to allow heterogeneous recycling of $\mathrm{BrO}_{x}$ to compete with $\mathrm{BrO}_{x}$ loss. Therefore, it appears reasonable that current understanding of bromine chemical kinetics is in agreement with this observed aerosol optical extinction threshold (aerosol extinction $>0.1 \mathrm{~km}^{-1}$ ) required for $\mathrm{BrO}$ to exist aloft.

Although we found that increased aerosol aloft was necessary for $\mathrm{BrO}$ to be found aloft, there were cases in which $\mathrm{BrO}$ remained ground based despite significant aerosol extinction above. For example, on 22 March, there was significant aerosol extinction aloft (Fig. 7), but BrO did not show signs of migrating aloft (Fig. 7). The lack of BrO aloft could be caused by hindered vertical mixing (Sect. 5.2) or by the particles having incorrect chemical composition to recycle reactive bromine. Therefore, we find that aerosol aloft is necessary for $\mathrm{BrO}$ to be present aloft, but it is not sufficient to always cause $\mathrm{BrO}$ to propagate vertically when enhanced aerosol extinction is present. Peterson et al. (2017) used airborne DOAS to study the case on 13 March and found that a reactive bromine plume propagated with the wind and was maintained by heterogeneous chemistry on aerosol particles, complementing the detailed cases explored in the present study.

\subsection{Sea-ice-lead-associated convection affected the BrO vertical profile}

On 23 March, after the opening of the sea ice lead, and on the following days (24 and $25 \mathrm{March}$ ) at the upwind IL1 site, $\mathrm{BrO}$ was present in a shallow layer $\left(f_{200}>0.5\right)$ with moderately enhanced $\left(2 \times 10^{13}\right.$ molecule $\left.\mathrm{cm}^{-2}\right)$ LT-VCD (Fig. 5). However, the sites near to and downwind of the lead (BARC and IL2) exhibited decreased $f_{200}$ values as compared to the upwind site, as would be expected by vertical entrainment of reactive-bromine-poor air from above the shallow boundary layer and mixing of surface air aloft. Consistent with decreased $f_{200}$, Fig. 7 shows this vertical mixing decreased the $\mathrm{BrO}$ surface mixing ratio downwind of the lead at IL2. As opposed to the clear surface mixing ratio decrease after lead opening, the BrO LT-VCD (Fig. 5) does not show strong differences between sites along the transport direction.

To further explore the effect of the lead opening event, Fig. 8 shows the average and variability of BrO LT-VCD and vertical distribution $\left(f_{200}\right)$ for 24-25 March, which were the 2 days following the lead opening event. During these 2 days, IL2 was downwind of a large area of re-freezing sea water, 71-106 km downwind of BARC. The typical surface wind speed was $\sim 5 \mathrm{~m} \mathrm{~s}^{-1}$ coming from $70^{\circ}$, nearly parallel to the BARC-IL2 direction. The wind speed increases aloft; averaged over the $0-600 \mathrm{~m}$ a.g.1. region, the Utqiagivik airport (PABR) radiosonde wind speeds were $\sim 8.5 \mathrm{~m} \mathrm{~s}^{-1}$, indicating a $2-3 \mathrm{~h}$ transport time. Figure 8 (left panel) demonstrates that the $\mathrm{BrO}$ column peaks at the middle (BARC) site and not the most downwind (IL2) site. On average, the $\mathrm{BrO}$ LT-VCD at IL1 (upwind) was somewhat (28\%) smaller than BARC, and IL2 was slightly (5\%) smaller than BARC. A paired $t$ test shows that the LT-VCD was statistically significantly larger at both BARC and IL2 than it was at IL1 but that the BARC and IL2 sites were statistically indistinguishable. Figure 8 (right panel) demonstrates a clear trend in the $f_{200}$ metric of $\mathrm{BrO}$ vertical distribution, with a shallower surface layer (larger $f_{200}$ ) at the upwind IL1 site trending towards a more vertically mixed layer (smaller $f_{200}$ ) at the downwind IL2 site. All sites are statistically significantly different from each other for $f_{200}$. These observations show that the open lead's primary influence was to alter the vertical distribution of $\mathrm{BrO}$, increasing its vertical extent, but the lead only slightly affected the BrO column density on the timescale of transport between these sites (up to about $3 \mathrm{~h}$ ).

The presence of the open and re-freezing leads could have had multiple effects on aerosol particles and BrO. Wind blowing across the lead is likely to produce aerosol particles (Nilsson et al., 2001; May et al., 2016), which could be lofted in the convective environment of the lead cloud. The lead is also re-freezing between BARC and IL2 during this period, and that new ice is likely covered with frost flowers, which have been proposed as either a direct source of reactive halogens (Rankin et al., 2002) or a source of sea salt aerosol particles (Kaleschke et al., 2004) that could subse- 

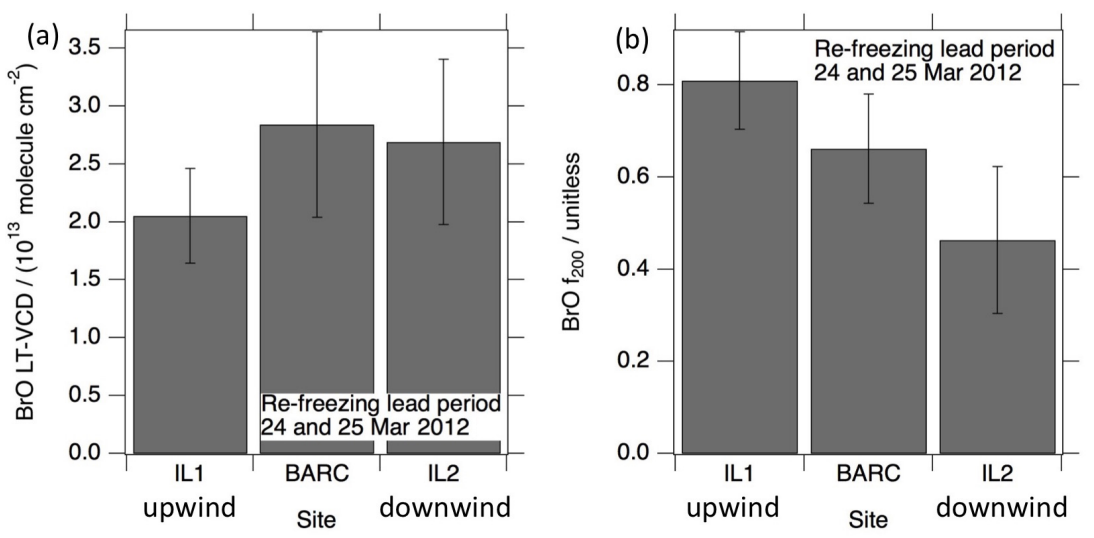

Figure 8. Average BrO LT-VCD (a) and BrO fraction in the lowest $200 \mathrm{~m}, f_{200}$, (b) during the 2 days after the lead opening, when the lead is open and re-freezing. The bar height is the average, and error bar length is $\pm 1 \sigma$. A $t$ test for significant difference $(\alpha=0.05)$ shows that the LT-VCD at BARC and IL2 was significantly larger than at IL1 but that BARC and IL2 were not significantly different. For the $f_{200}$ vertical distribution metric, all three sites were statistically different from each other with a clear trend from the upwind IL1 site to the downwind IL2 site.

quently produce/recycle reactive bromine via Reaction (3). Figure 7 shows the lead opening event produced high extinction $\left(>1 \mathrm{~km}^{-1}\right)$ through $\sim 600 \mathrm{~m}$ altitude on 23 March, and this aerosol-cloud layer persisted into the morning of 24 March. Note that MAX-DOAS measures aerosol extinction by attenuation of $\mathrm{O}_{4}$ absorption path length, so all submicron aerosol particles, supermicron particles, and solid/liquid water droplets in a cloud will increase the aerosol extinction. Interestingly, the aerosol extinction at IL2 on the afternoon of 24 March is lower than at the other sites, potentially due to enhanced scavenging by the humid lead cloud environment. On 25 March, Fig. 5 shows that the AOD at BARC and IL2 went below 0.2 , also potentially caused by scavenging and/or reduced wind speeds (Fig. 2). Piot and von Glasow (2008) modeled interaction of an air mass with an open lead and found that the presence of supercooled liquid water droplets suppresses heterogeneous bromine recycling, which may be relevant to the lead re-freezing event. Examination of the MODIS sea ice images (animation in the Supplement) shows that IL2 is not cloudy on both 24 and 25 March, but some clouds are seen between BARC and IL2. Overall, the response to the lead opening of aerosol extinction, as measured by MAX-DOAS, was a peak in aerosol extinction that corresponded with the highest winds especially at the most downwind site (IL2) and then lower aerosol levels as winds slowed and the lead re-froze. Following the passage of the lead cloud, which cleared around noon on 24 March, aerosol extinction (Fig. 7) does not appear to be enhanced at the downwind site (IL2) as compared to the other sites, potentially indicating that open water and/or frost flowers between BARC and IL2 are not efficient aerosol particle sources, at least at this surface wind speed (which dropped to $\sim 4 \mathrm{~m} \mathrm{~s}^{-1}$ ).

With regard to $\mathrm{BrO}$ observations on the 2 days following lead opening, Fig. 8 showed that BrO LT-VCD increased
$28 \%$ from IL1 to BARC but decreased $5 \%$ from BARC to IL2. The origin of the moderate increase from IL1 to BARC is not clear, but Peterson et al. (2015) found that shallower layers (as are observed at IL1 as compared to BARC) are correlated with lower LT-VCD, so the deepening of the $\mathrm{BrO}$ layer, and heterogeneous reactions on lofted aerosol particles, between IL1 and BARC could be responsible for that moderate increase in BrO. MODIS images (see animation in the Supplement) show that the lead between BARC and IL2 is re-freezing in this period; given the cold temperatures $\left(-23\right.$ to $\left.-32^{\circ} \mathrm{C}\right)$, humidity from the open water, and presence of re-freezing sea ice, it is highly likely that the area between BARC and IL2 contained frost flowers, which have been suggested to be a source of reactive bromine (Rankin et al., 2002; Kaleschke et al., 2004). However, we see a small decrease in $\mathrm{BrO}$ from BARC to IL2, which argues against frost flowers being a direct source of reactive bromine, consistent with recent laboratory studies (Roscoe et al., 2011; Yang et al., 2017).

\subsection{Relationship of these findings to prior studies}

These data show that vertical mixing deepens the atmospheric layer containing $\mathrm{BrO}$ through lead-induced vertical mixing. Peterson et al. (2015) found that more vertically mixed $\mathrm{BrO}$ events are correlated with higher $\mathrm{BrO}$ column amounts. McElroy et al. (1999) observed a large tropospheric $\mathrm{BrO}$ column from high-altitude aircraft and associated this column with sea-ice-lead-induced vertical mixing, consistent with our observations. Satellite-based spectrometers detect the total (tropospheric + stratospheric) BrO column density, which can be corrected for stratospheric $\mathrm{BrO}$ (Theys et al., 2011; Choi et al., 2012; Sihler et al., 2012) to give a tropospheric VCD, but satellite sensors cannot determine vertical profiles of $\mathrm{BrO}$ and may not observe shallow $\mathrm{BrO}$ events, 
which were common during BROMEX. Thus, surface (e.g., ground-based CIMS or MAX-DOAS) observations would indicate differing environmental controls for halogen activation than satellites would have indicated. These types of differences in environmental controls have been noted in the literature, depending upon the type of sensor (satellite versus ground based) that was used to quantify halogen activation (BrO). Jones et al. (2009) and Yang et al. (2010) found that satellite-detected $\mathrm{BrO}$ is associated with high winds that would decrease atmospheric stability and thus cause vertical mixing much like the lead-induced mixing in this example and increase visibility of $\mathrm{BrO}$ from space. However, there may also be differences in wind speed regime between Antarctic (Jones et al., 2009; Yang et al., 2010; Theys et al., 2011) and Arctic observations.

The finding that $\mathrm{BrO}$ is not increased downwind of frost flowers is in agreement with measurements of their chemical composition, which has incorrect $\mathrm{pH}$ for reactive bromine production (Kalnajs and Avallone, 2006; Abbatt et al., 2012; Pratt et al., 2013). It is possible that the "potential frost flowers" (PFF) metric (Kaleschke et al., 2004), which was devised to diagnose regions of frost flower formation and which involved a combination of open water and cold temperatures, could have been diagnosing spatial regions where leadinduced vertical mixing was occurring (Nghiem et al., 2012), which are correlated with higher BrO LT-VCD (Peterson et al., 2015). Therefore, the correlation of PFF with satelliteobserved $\mathrm{BrO}$ could be expected, not because frost flowers are directly responsible for halogen activation but because vertical mixing associated with the PFF proxy enhances the thickness of the BrO layer.

Airborne observations of $\mathrm{BrO}$ were targeted during the NASA ARCTAS field mission to locations of high satellitedetected $\mathrm{BrO}$ column densities, but little in situ $\mathrm{BrO}$ was found (Jacob et al., 2010). This finding is again consistent with our observations - regions of high column $\mathrm{BrO}$ are vertically mixed, leading to lower in situ mixing ratios of $\mathrm{BrO}$, and thus less detectable by aircraft in situ techniques. Recent studies (Jones et al., 2009; Begoin et al., 2010; Toyota et al., 2011; Choi et al., 2012) have found that mesoscale cyclonic storms that have high winds that destabilize the otherwise stable Arctic atmosphere are associated with multi-day satellite-remote-sensed $\mathrm{BrO}$ transport events, again in agreement with the finding that vertical mixing enhances the $\mathrm{BrO}$ column density (Peterson et al., 2015).

\section{Conclusions}

Analysis of time series of the BrO LT-VCD and fraction of $\mathrm{BrO}$ in the lowest $200 \mathrm{~m}\left(f_{200}\right)$ at Barrow (Utqiagivik) gave the following results. When a large sea ice lead opened and the ocean re-froze, the vertical distribution of $\mathrm{BrO}$ was affected, but no significant increase in BrO LT-VCD was observed between BARC and IL2, which was downwind of the re-freezing lead, providing a counterexample to the hypothesis that frost flowers growing on sea ice are a direct source of BrO. Measurements of BrO LT-VCD and $f_{200}$ were highly correlated on $\sim 30 \mathrm{~km}$ length scales when there were no sources of vertical mixing (e.g., open leads) in the intervening area. During the BROMEX period, which was characterized by clear skies and cold temperatures that enhance vertical stability, shallow surface-based $\mathrm{BrO}$ events were common. Repartitioning of $\mathrm{BrO}_{x}$ due to low ozone levels caused low surface $\mathrm{BrO}$ mixing ratios; depending upon whether reactive bromine recycling was efficient aloft, $\mathrm{BrO}$ either shifted to higher altitude, becoming a lofted layer, or decreased through the column. Aerosol extinction aloft was necessary but not sufficient for $\mathrm{BrO}$ to be present aloft. An aerosol extinction larger than $0.1 \mathrm{~km}^{-1}$ appeared necessary for maintaining $\mathrm{BrO}$ aloft. These detailed observations can be further used in modeling studies that provide insights into how chemistry and meteorology interact (Holmes et al., 2006, 2010; Thomas et al., 2011, 2012, Toyota et al., 2011, 2014).

These observations highlight spatial features of $\mathrm{BrO}$ events in the Arctic and their relationship to aerosol extinction. Vertical atmospheric structure (stability) is a critical control on the nature of reactive bromine events, with typical "inverted" temperature profiles holding BrO close to the snowpack (Frieß et al., 2011; Peterson et al., 2015), where halogen activation reactions occur (Pratt et al., 2013). Punctuated vertical mixing events, either by sea-ice-lead-induced convection or by high winds associated with storms, dilute the surface mixing ratio, but these more vertically mixed events are correlated with enhanced $\mathrm{BrO}$ column density. These detailed observations resolve many past controversies with respect to halogen activation in the Arctic. The Arctic sea ice pack is thinning, and multi-year ice is being replaced by seasonal first-year ice (Maslanik et al., 2011), which has been predicted to increase the occurrence of leads and has been predicted to have many further implications (Bhatt et al., 2014). Moore et al. (2014) showed that ozone and mercury are brought down from aloft during these lead events. In this work, we showed that reactive bromine was brought up from near the surface to a thicker layer by a lead-induced mixing event. These two factors should increase the overlap of mercury with reactive bromine and thus the oxidation and deposition of mercury to the Arctic. Predictions of increased sea ice leads would thus be expected to increase the amount of toxic mercury deposition and have a greater impact on Arctic free-tropospheric $\mathrm{O}_{3}$.

Data availability. Data from this project are accessible at https:// nex.nasa.gov/nex/projects/1388/ (Simpson et al., 2016).

The Supplement related to this article is available online at https://doi.org/10.5194/acp-17-9291-2017-supplement. 
Competing interests. The authors declare that they have no conflict of interest.

Acknowledgements. This work was supported by the National Aeronautics and Space Administration (NASA) Cryospheric Sciences Program (CSP), using methods supported by the National Science Foundation under grant ARC-1023118, and by the University of Alaska Fairbanks and the Desert Research Institute. The research at the Jet Propulsion Laboratory, California Institute of Technology, was supported by the NASA CSP and by the NASA Atmospheric Composition Program. The research at the University of Michigan was supported by the NASA Earth Science Research Program (NNX14AP44G). We thank Bristow Helicopters and Umiaq for field logistic assistance and the National Oceanic and Atmosphere Administration (NOAA) Global Monitoring Division for the Barrow (Utqiagivik) Observatory data. We thank Alexei Rozanov from IUP Bremen for providing the SCIATRAN radiative transfer model. We thank Todd Valentic (SRI), Steven Walsh (UAF), Don Perovich (CRREL), and Matthew Sturm (UAF) for assistance in deploying instruments and telemetry of data.

Edited by: Anna Jones

Reviewed by: two anonymous referees

\section{References}

Abbatt, J. P. D., Thomas, J. L., Abrahamsson, K., Boxe, C., Granfors, A., Jones, A. E., King, M. D., Saiz-Lopez, A., Shepson, P. B., Sodeau, J., Toohey, D. W., Toubin, C., von Glasow, R., Wren, S. N., and Yang, X.: Halogen activation via interactions with environmental ice and snow in the polar lower troposphere and other regions, Atmos. Chem. Phys., 12, 6237-6271, https://doi.org/10.5194/acp-12-6237-2012, 2012.

Barrie, L. A., Bottenheim, J. W., Schnell, R. C., Crutzen, P. J., and Rasmussen, R. A.: Ozone destruction and photochemical reactions at polar sunrise in the lower Arctic atmosphere, Nature, 334, 138-141, 1988.

Begoin, M., Richter, A., Weber, M., Kaleschke, L., Tian-Kunze, X., Stohl, A., Theys, N., and Burrows, J. P.: Satellite observations of long range transport of a large $\mathrm{BrO}$ plume in the Arctic, Atmos. Chem. Phys., 10, 6515-6526, https://doi.org/10.5194/acp10-6515-2010, 2010.

Bhatt, U. S., Walker, D. A., Walsh, J. E., Carmack, E. C., Frey, K. E., Meier, W. N., Moore, S. E., Parmentier, F.-J. W., Post, E., Romanovsky, V. E., and Simpson, W. R.: Implications of Arctic Sea Ice Decline for the Earth System, Annu. Rev. Env. Resour., 39, 57-89, https://doi.org/10.1146/annurevenviron-122012-094357, 2014.

Carlson, D., Donohoue, D., Platt, U., and Simpson, W. R.: A low power automated MAX-DOAS instrument for the Arctic and other remote unmanned locations, Atmos. Meas. Tech., 3, 429439, https://doi.org/10.5194/amt-3-429-2010, 2010.

Choi, S., Wang, Y., Salawitch, R. J., Canty, T., Joiner, J., Zeng, T., Kurosu, T. P., Chance, K., Richter, A., Huey, L. G., Liao, J., Neuman, J. A., Nowak, J. B., Dibb, J. E., Weinheimer, A. J., Diskin, G., Ryerson, T. B., da Silva, A., Curry, J., Kinnison, D., Tilmes,
S., and Levelt, P. F.: Analysis of satellite-derived Arctic tropospheric BrO columns in conjunction with aircraft measurements during ARCTAS and ARCPAC, Atmos. Chem. Phys., 12, 12551285, https://doi.org/10.5194/acp-12-1255-2012, 2012.

Evans, M. J.: Coupled evolution of $\mathrm{BrO}_{x}-\mathrm{ClO}_{x}-\mathrm{HO}_{x}-\mathrm{NO}_{x}$ chemistry during bromine-catalyzed ozone depletion events in the arctic boundary layer, J. Geophys. Res., 108, 8368, https://doi.org/10.1029/2002JD002732, 2003.

Fan, S.-M. and Jacob, D. J.: Surface ozone depletion in Arctic spring sustained by bromine reactions on aerosols, Nature, 359, 522-524, 1992.

Fickert, S., Adams, J. W., and Crowley, J. N.: Activation of $\mathrm{Br}_{2}$ and $\mathrm{BrCl}$ via uptake of $\mathrm{HOBr}$ onto aqueous salt solutions, J. Geophys. Res., 104, 23719-23727, 1999.

Frieß, U., Sihler, H., Sander, R., Pöhler, D., Yilmaz, S., and Platt, U.: The vertical distribution of $\mathrm{BrO}$ and aerosols in the Arctic: Measurements by active and passive differential optical absorption spectroscopy, J. Geophys. Res.-Atmos., 116, D00R04, https://doi.org/10.1029/2011JD015938, 2011.

Gilman, J. B., Burkhart, J. F., Lerner, B. M., Williams, E. J., Kuster, W. C., Goldan, P. D., Murphy, P. C., Warneke, C., Fowler, C., Montzka, S. A., Miller, B. R., Miller, L., Oltmans, S. J., Ryerson, T. B., Cooper, O. R., Stohl, A., and de Gouw, J. A.: Ozone variability and halogen oxidation within the Arctic and sub-Arctic springtime boundary layer, Atmos. Chem. Phys., 10, 1022310236, https://doi.org/10.5194/acp-10-10223-2010, 2010.

Grannas, A. M., Jones, A. E., Dibb, J., Ammann, M., Anastasio, C., Beine, H. J., Bergin, M., Bottenheim, J., Boxe, C. S., Carver, G., Chen, G., Crawford, J. H., Dominé, F., Frey, M. M., Guzmán, M. I., Heard, D. E., Helmig, D., Hoffmann, M. R., Honrath, R. E., Huey, L. G., Hutterli, M., Jacobi, H. W., Klán, P., Lefer, B., McConnell, J., Plane, J., Sander, R., Savarino, J., Shepson, P. B., Simpson, W. R., Sodeau, J. R., von Glasow, R., Weller, R., Wolff, E. W., and Zhu, T.: An overview of snow photochemistry: evidence, mechanisms and impacts, Atmos. Chem. Phys., 7, 43294373, https://doi.org/10.5194/acp-7-4329-2007, 2007.

Halfacre, J. W., Knepp, T. N., Shepson, P. B., Thompson, C. R., Pratt, K. A., Li, B., Peterson, P. K., Walsh, S. J., Simpson, W. R., Matrai, P. A., Bottenheim, J. W., Netcheva, S., Perovich, D. K., and Richter, A.: Temporal and spatial characteristics of ozone depletion events from measurements in the Arctic, Atmos. Chem. Phys., 14, 4875-4894, https://doi.org/10.5194/acp14-4875-2014, 2014.

Helmig, D., Boylan, P., Johnson, B., Oltmans, S., Fairall, C., Staebler, R., Weinheimer, A., Orlando, J., Knapp, D. J., Montzka, D. D., Flocke, F., Frieß, U., Sihler, H., and Shepson, P. B.: Ozone dynamics and snow-atmosphere exchanges during ozone depletion events at Barrow, Alaska, J. Geophys. Res.-Atmos., 117, D20303, https://doi.org/10.1029/2012JD017531, 2012.

Holmes, C. D., Jacob, D. J., and Yang, X.: Global lifetime of elemental mercury against oxidation by atomic bromine in the free troposphere, Geophys. Res. Lett., 33, L20808, https://doi.org/10.1029/2006GL027176, 2006.

Holmes, C. D., Jacob, D. J., Mason, R. P., and Jaffe, D. A.: Sources and deposition of reactive gaseous mercury in the marine atmosphere, Atmos. Environ., 43, 2278-2285, https://doi.org/10.1016/j.atmosenv.2009.01.051, 2009.

Holmes, C. D., Jacob, D. J., Corbitt, E. S., Mao, J., Yang, X., Talbot, R., and Slemr, F.: Global atmospheric model for mer- 
cury including oxidation by bromine atoms, Atmos. Chem. Phys., 10, 12037-12057, https://doi.org/10.5194/acp-10-120372010, 2010.

Hornbrook, R. S., Hills, A. J., Riemer, D. D., Abdelhamid, A., Flocke, F. M., Hall, S. R., Huey, L. G., Knapp, D. J., Liao, J., Mauldin, R. L., Montzka, D. D., Orlando, J. J., Shepson, P. B., Sive, B., Staebler, R. M., Tanner, D. J., Thompson, C. R., Turnipseed, A., Ullmann, K., Weinheimer, A. J., and Apel, E. C.: Arctic springtime observations of volatile organic compounds during the OASIS-2009 campaign, J. Geophys. Res.-Atmos., 121, 9789-9813, https://doi.org/10.1002/2015JD024360, 2016.

Huff, A. K. and Abbatt, J. P. D.: Gas-Phase $\mathrm{Br}_{2}$ Production in Heterogeneous Reactions of $\mathrm{Cl}_{2}, \mathrm{HOCl}$, and $\mathrm{BrCl}$ with Halide-Ice Surfaces, J. Phys. Chem. A, 104, 7284-7293, 2000.

Huff, A. K. and Abbatt, J. P. D.: Kinetics and Product Yields in the Heterogeneous Reactions of $\mathrm{HOBr}$ with Ice Surfaces Containing $\mathrm{NaBr}$ and $\mathrm{NaCl}$, J. Phys. Chem. A, 106, 5279-5287, https://doi.org/10.1021/jp014296m, 2002.

Hunt, S. W., Roeselová, M., Wang, W., Wingen, L. M., Knipping, E. M., Tobias, D. J., Dabdub, D., and Finlayson-Pitts, B. J.: Formation of Molecular Bromine from the Reaction of Ozone with Deliquesced $\mathrm{NaBr}$ Aerosol: Evidence for Interface Chemistry, J. Phys. Chem. A, 108, 11559-11572, https://doi.org/10.1021/jp0467346, 2004.

Jacob, D. J., Crawford, J. H., Maring, H., Clarke, A. D., Dibb, J. E., Emmons, L. K., Ferrare, R. A., Hostetler, C. A., Russell, P. B., Singh, H. B., Thompson, A. M., Shaw, G. E., McCauley, E., Pederson, J. R., and Fisher, J. A.: The Arctic Research of the Composition of the Troposphere from Aircraft and Satellites (ARCTAS) mission: design, execution, and first results, Atmos. Chem. Phys., 10, 5191-5212, https://doi.org/10.5194/acp10-5191-2010, 2010.

Jacobi, H.-W., Morin, S., and Bottenheim, J. W.: Observation of widespread depletion of ozone in the springtime boundary layer of the central Arctic linked to mesoscale synoptic conditions, J. Geophys. Res., 115, D17302, https://doi.org/10.1029/2010JD013940, 2010.

Jobson, B. T., Niki, H., Yokouchi, Y., Bottenheim, J., Hopper, F., and Leaitch, R.: Measurements of C2-C6 hydrocarbons during the Polar Sunrise1992 Experiment: Evidence for $\mathrm{Cl}$ atom and $\mathrm{Br}$ atom chemistry, J. Geophys. Res., 99, 25355-25368, https://doi.org/10.1029/94JD01243, 1994.

Jones, A. E., Anderson, P. S., Begoin, M., Brough, N., Hutterli, M. A., Marshall, G. J., Richter, A., Roscoe, H. K., and Wolff, E. W.: BrO, blizzards, and drivers of polar tropospheric ozone depletion events, Atmos. Chem. Phys., 9, 4639-4652, https://doi.org/10.5194/acp-9-4639-2009, 2009.

Kaleschke, L., Richter, A., Burrows, J., Afe, O., Heygster, G., Notholt, J., Rankin, A. M., Roscoe, H. K., Hollwedel, J., Wagner, T., and Jacobi, H.-W.: Frost flowers on sea ice as a source of sea salt and their influence on tropospheric halogen chemistry, Geophys. Res. Lett., 31, L16114, https://doi.org/10.1029/2004GL020655, 2004.

Kalnajs, L. E. and Avallone, L. M.: Frost flower influence on springtime boundary-layer ozone depletion events and atmospheric bromine levels, Geophys. Res. Lett., 33, L10810, https://doi.org/10.1029/2006GL025809, 2006.

Krnavek, L., Simpson, W. R., Carlson, D., Domine, F., Douglas, T. A., and Sturm, M.: The chemical composition of surface snow in the Arctic: Examining marine, terrestrial, and atmospheric influences, Atmos. Environ., 50, 349-359, https://doi.org/10.1016/j.atmosenv.2011.11.033, 2012.

Lehrer, E., Hönninger, G., and Platt, U.: A one dimensional model study of the mechanism of halogen liberation and vertical transport in the polar troposphere, Atmos. Chem. Phys., 4, $2427-$ 2440, https://doi.org/10.5194/acp-4-2427-2004, 2004.

Maslanik, J., Stroeve, J., Fowler, C., and Emery, W.: Distribution and trends in Arctic sea ice age through spring 2011, Geophys. Res. Lett., 38, L13502, https://doi.org/10.1029/2011GL047735, 2011.

May, N. W., Quinn, P. K., McNamara, S. M., and Pratt, K. A.: Multiyear study of the dependence of sea salt aerosol on wind speed and sea ice conditions in the coastal Arctic, J. Geophys. Res.-Atmos., 121, 9208-9219, https://doi.org/10.1002/2016JD025273, 2016.

McClure-Begley, A., Petropavlovskikh, I., and Oltmans, S.: NOAA Global Monitoring Surface Ozone Network. 1973-2014, NOAA/ESRL/GMD, Boulder, CO, https://doi.org/10.7289/V57P8WBF, 2014.

McElroy, C. T., McLinden, C. A., and McConnell, J. C.: Evidence for bromine monoxide in the free troposphere during the Arctic polar sunrise, Nature, 397, 338-341, https://doi.org/10.1038/16904, 1999.

Moore, C. W., Obrist, D., Steffen, A., Staebler, R. M., Douglas, T. A., Richter, A., and Nghiem, S. V: Convective forcing of mercury and ozone in the Arctic boundary layer induced by leads in sea ice, Nature, 506, 81-84, https://doi.org/10.1038/nature12924, 2014.

Nghiem, S. V., Rigor, I. G., Perovich, D. K., Clemente-Colón, P., Weatherly, J. W., and Neumann, G.: Rapid reduction of Arctic perennial sea ice, Geophys. Res. Lett., 34, L19504, https://doi.org/10.1029/2007GL031138, 2007.

Nghiem, S. V., Rigor, I. G., Richter, A., Burrows, J. P., Shepson, P. B., Bottenheim, J., Barber, D. G., Steffen, A., Latonas, J., Wang, F., Stern, G., Clemente-Colón, P., Martin, S., Hall, D. K., Kaleschke, L., Tackett, P., Neumann, G., and Asplin, M. G.: Field and satellite observations of the formation and distribution of Arctic atmospheric bromine above a rejuvenated sea ice cover, J. Geophys. Res.-Atmos., 117, D00S05, https://doi.org/10.1029/2011JD016268, 2012.

Nghiem, S. V., Clemente-Colón, P., Douglas, T., Moore, C., Obrist, D., Perovich, D. K., Pratt, K. A., Rigor, I. G., Simpson, W., Shepson, P. B., Steffen, A., and Woods, J.: Studying Bromine, Ozone, and Mercury Chemistry in the Arctic, Eos, T. Am. Geophys. Un., 94, 289-291, https://doi.org/10.1002/2013EO330002, 2013.

Nilsson, E. D., Rannik, Ü., Swietlicki, E., Leck, C., Aalto, P. P., Zhou, J., and Norman, M.: Turbulent aerosol fluxes over the Arctic Ocean: 2. Wind-driven sources from the sea, J. Geophys. Res.-Atmos., 106, 32139-32154, https://doi.org/10.1029/2000JD900747, 2001.

Oltmans, S. J., Johnson, B. J., and Harris, J. M.: Springtime boundary layer ozone depletion at Barrow, Alaska: Meteorological influence, year-to-year variation, and long-term change, J. Geophys. Res., 117, D00R18, https://doi.org/10.1029/2011JD016889, 2012.

Oum, K. W., Lakin, M. J., and Finlayson-Pitts, B. J.: Bromine activation in the troposphere by the dark reaction of $\mathrm{O}$ 
3 with seawater ice, Geophys. Res. Lett., 25, 3923-3926, https://doi.org/10.1029/1998GL900078, 1998.

Payne, V. H., Clough, S. A., Shephard, M. W., Nassar, R., and Logan, J. A.: Information-centered representation of retrievals with limited degrees of freedom for signal: Application to methane from the Tropospheric Emission Spectrometer, J. Geophys. Res., 114, D10307, https://doi.org/10.1029/2008JD010155, 2009.

Peterson, P. K., Simpson, W. R., Pratt, K. A., Shepson, P. B., Frieß, U., Zielcke, J., Platt, U., Walsh, S. J., and Nghiem, S. V.: Dependence of the vertical distribution of bromine monoxide in the lower troposphere on meteorological factors such as wind speed and stability, Atmos. Chem. Phys., 15, 2119-2137, https://doi.org/10.5194/acp-15-2119-2015, 2015.

Peterson, P. K., Simpson, W. R., and Nghiem, S. V.: Variability of bromine monoxide at Barrow, Alaska, over four halogen activation (March-May) seasons and at two onice locations, J. Geophys. Res.-Atmos., 121, 1381-1396, https://doi.org/10.1002/2015JD024094, 2016.

Peterson, P. K., Pöhler, D., Sihler, H., Zielcke, J., General, S., Frieß, U., Platt, U., Simpson, W. R., Nghiem, S. V., Shepson, P. B., Stirm, B. H., Dhaniyala, S., Wagner, T., Caulton, D. R., Fuentes, J. D., and Pratt, K. A.: Observations of bromine monoxide transport in the Arctic sustained on aerosol particles, Atmos. Chem. Phys., 17, 7567-7579, https://doi.org/10.5194/acp17-7567-2017, 2017.

Piot, M. and von Glasow, R.: The potential importance of frost flowers, recycling on snow, and open leads for ozone depletion events, Atmos. Chem. Phys., 8, 2437-2467, https://doi.org/10.5194/acp-8-2437-2008, 2008.

Platt, U. and Hönninger, G.: The role of halogen species in the troposphere, Chemosphere, 52, 325-338, 2003.

Pratt, K. A., Custard, K. D., Shepson, P. B., Douglas, T. A., Pöhler, D., General, S., Zielcke, J., Simpson, W. R., Platt, U., Tanner, D. J., Gregory Huey, L., Carlsen, M., and Stirm, B. H.: Photochemical production of molecular bromine in Arctic surface snowpacks, Nat. Geosci., 6, 351-356, https://doi.org/10.1038/ngeo1779, 2013.

Quinn, P. K., Miller, T. L., Bates, T. S., Ogren, J. A., Andrews, E., and Shaw, G. E.: A 3-year record of simultaneously measured aerosol chemical and optical properties at Barrow, Alaska, J. Geophys. Res.-Atmos., 107, AAC 8-1-AAC 8-15, https://doi.org/10.1029/2001JD001248, 2002.

Rankin, A. M., Wolff, E. W., and Martin, S.: Frost flowers: Implications for tropospheric chemistry and ice core interpretation, J. Geophys. Res.-Atmos., 107, AAC 4-1-AAC 4-15, https://doi.org/10.1029/2002JD002492, 2002.

Richter, A., Wittrock, F., Eisinger, M., and Burrows, J. P.: GOME observations of tropospheric $\mathrm{BrO}$ in northern hemispheric spring and summer 1997, Geophys. Res. Lett., 25, 26832686, https://doi.org/10.1029/98GL52016, 1998.

Roberts, T. J., Jourdain, L., Griffiths, P. T., and Pirre, M.: Re-evaluating the reactive uptake of $\mathrm{HOBr}$ in the troposphere with implications for the marine boundary layer and volcanic plumes, Atmos. Chem. Phys., 14, 11185-11199, https://doi.org/10.5194/acp-14-11185-2014, 2014.

Roscoe, H. K., Brooks, B., Jackson, A. V., Smith, M. H., Walker, S. J., Obbard, R. W., and Wolff, E. W.: Frost flowers in the laboratory: Growth, characteristics, aerosol, and the underlying sea ice, J. Geophys. Res., 116, D12301, https://doi.org/10.1029/2010JD015144, 2011.

Rozanov, A., Rozanov, V., Buchwitz, M., Kokhanovsky, A., and Burrows, J. P.: SCIATRAN 2.0 - A new radiative transfer model for geophysical applications in the 175$2400 \mathrm{~nm}$ spectral region, Adv. Space Res., 36, 1015-1019, https://doi.org/10.1016/j.asr.2005.03.012, 2005.

Salawitch, R. J., Canty, T., Kurosu, T., Chance, K., Liang, Q., da Silva, A., Pawson, S., Nielsen, J. E., Rodriguez, J. M., Bhartia, P. K., Liu, X., Huey, L. G., Liao, J., Stickel, R. E., Tanner, D. J., Dibb, J. E., Simpson, W. R., Donohoue, D., Weinheimer, A., Flocke, F., Knapp, D., Montzka, D., Neuman, J. A. Nowak, J. B., Ryerson, T. B., Oltmans, S., Blake, D. R., Atlas, E. L., Kinnison, D. E., Tilmes, S., Pan, L. L., Hendrick, F., Van Roozendael, M., Kreher, K., Johnston, P. V, Gao, R. S., Johnson, B., Bui, T. P., Chen, G., Pierce, R. B., Crawford, J. H., and Jacob, D. J.: A new interpretation of total column BrO during Arctic spring, Geophys. Res. Lett., 37, L21805, https://doi.org/10.1029/2010GL043798, 2010.

Sander, R., Vogt, R., Harris, G. W., and Crutzen, P. J.: Modelling the chemistry of ozone, halogen compounds, and hydrocarbons in the arctic troposphere during spring, Tellus B, 49B, 522-532, https://doi.org/10.3402/tellusb.v45i5.16001, 1997.

Schroeder, W. H., Anlauf, K. G., Barrie, L. A., Lu, J. Y., Steffen, A., Schneeberger, D. R., and Berg, T.: Arctic springtime depletion of mercury, Nature, 394, 331-332, https://doi.org/10.1038/28530, 1998.

Sihler, H., Platt, U., Beirle, S., Marbach, T., Kühl, S., Dörner, S., Verschaeve, J., Frieß, U., Pöhler, D., Vogel, L., Sander, R., and Wagner, T.: Tropospheric BrO column densities in the Arctic derived from satellite: retrieval and comparison to ground-based measurements, Atmos. Meas. Tech., 5, 2779 2807, https://doi.org/10.5194/amt-5-2779-2012, 2012.

Simpson, W. R., Alvarez-Aviles, L., Douglas, T. A., Sturm, M., and Domine, F.: Halogens in the coastal snow pack near Barrow, Alaska: Evidence for active bromine air-snow chemistry during springtime, Geophys. Res. Lett., 32, L04811, https://doi.org/10.1029/2004GL021748, 2005.

Simpson, W. R., Carlson, D., Hönninger, G., Douglas, T. A., Sturm, M., Perovich, D., and Platt, U.: First-year sea-ice contact predicts bromine monoxide $(\mathrm{BrO})$ levels at Barrow, Alaska better than potential frost flower contact, Atmos. Chem. Phys., 7, 621-627, https://doi.org/10.5194/acp-7-621-2007, 2007a.

Simpson, W. R., von Glasow, R., Riedel, K., Anderson, P., Ariya, P., Bottenheim, J., Burrows, J., Carpenter, L. J., Frieß, U., Goodsite, M. E., Heard, D., Hutterli, M., Jacobi, H.-W., Kaleschke, L., Neff, B., Plane, J., Platt, U., Richter, A., Roscoe, H., Sander, R., Shepson, P., Sodeau, J., Steffen, A., Wagner, T., and Wolff, E.: Halogens and their role in polar boundary-layer ozone depletion, Atmos. Chem. Phys., 7, 4375-4418, https://doi.org/10.5194/acp7-4375-2007, 2007b.

Simpson, W. R., Brown, S. S., Saiz-Lopez, A., Thornton, J. A., and Glasow, R. von: Tropospheric Halogen Chemistry: Sources, Cycling, and Impacts, Chem. Rev., 115, 4035-4062, https://doi.org/10.1021/cr5006638, 2015.

Simpson, W. R., Peterson, P. K., and Nghiem, S. V.: Implications of Arctic Sea Ice Reduction on Tropospheric Bromine, Ozone, and Mercury Chemical Processes, Transport, and Distri- 
bution: MAX-DOAS data, available at: https://nex.nasa.gov/nex/ projects/1388/ (last access: 15 June 2017), 2016.

Steffen, A., Douglas, T., Amyot, M., Ariya, P., Aspmo, K., Berg, T., Bottenheim, J., Brooks, S., Cobbett, F., Dastoor, A., Dommergue, A., Ebinghaus, R., Ferrari, C., Gardfeldt, K., Goodsite, M. E., Lean, D., Poulain, A. J., Scherz, C., Skov, H., Sommar, J., and Temme, C.: A synthesis of atmospheric mercury depletion event chemistry in the atmosphere and snow, Atmos. Chem. Phys., 8, 1445-1482, https://doi.org/10.5194/acp-8-1445-2008, 2008.

Stephens, C. R., Shepson, P. B., Steffen, A., Bottenheim, J. W., Liao, J., Huey, L. G., Apel, E., Weinheimer, A., Hall, S. R., Cantrell, C., Sive, B. C., Knapp, D. J., Montzka, D. D., and Hornbrook, R. S.: The relative importance of chlorine and bromine radicals in the oxidation of atmospheric mercury at Barrow, Alaska, J. Geophys. Res.-Atmos., 117, D00R11, https://doi.org/10.1029/2011JD016649, 2012.

Stroeve, J. C., Serreze, M. C., Holland, M. M., Kay, J. E., Malanik, J., and Barrett, A. P.: The Arctic's rapidly shrinking sea ice cover: a research synthesis, Clim. Change, 110, 1005-1027, https://doi.org/10.1007/s10584-011-0101-1, 2012.

Theys, N., Van Roozendael, M., Errera, Q., Hendrick, F., Daerden, F., Chabrillat, S., Dorf, M., Pfeilsticker, K., Rozanov, A., Lotz, W., Burrows, J. P., Lambert, J.-C., Goutail, F., Roscoe, H. K., and De Mazière, M.: A global stratospheric bromine monoxide climatology based on the BASCOE chemical transport model, Atmos. Chem. Phys., 9, 831-848, https://doi.org/10.5194/acp-9831-2009, 2009.

Theys, N., Van Roozendael, M., Hendrick, F., Yang, X., De Smedt, I., Richter, A., Begoin, M., Errera, Q., Johnston, P. V., Kreher, K., and De Mazière, M.: Global observations of tropospheric BrO columns using GOME-2 satellite data, Atmos. Chem. Phys., 11, 1791-1811, https://doi.org/10.5194/acp-11-1791-2011, 2011.

Thomas, J. L., Stutz, J., Lefer, B., Huey, L. G., Toyota, K., Dibb, J. E., and von Glasow, R.: Modeling chemistry in and above snow at Summit, Greenland - Part 1: Model description and results, Atmos. Chem. Phys., 11, 4899-4914, https://doi.org/10.5194/acp11-4899-2011, 2011.

Thomas, J. L., Dibb, J. E., Huey, L. G., Liao, J., Tanner, D., Lefer, B., von Glasow, R., and Stutz, J.: Modeling chemistry in and above snow at Summit, Greenland - Part 2: Impact of snowpack chemistry on the oxidation capacity of the boundary layer, Atmos. Chem. Phys., 12, 6537-6554, https://doi.org/10.5194/acp12-6537-2012, 2012.
Thompson, C. R., Shepson, P. B., Liao, J., Huey, L. G., Apel, E. C., Cantrell, C. A., Flocke, F., Orlando, J., Fried, A., Hall, S. R., Hornbrook, R. S., Knapp, D. J., Mauldin III, R. L., Montzka, D. D., Sive, B. C., Ullmann, K., Weibring, P., and Weinheimer, A.: Interactions of bromine, chlorine, and iodine photochemistry during ozone depletions in Barrow, Alaska, Atmos. Chem. Phys., 15, 9651-9679, https://doi.org/10.5194/acp15-9651-2015, 2015.

Toyota, K., McConnell, J. C., Lupu, A., Neary, L., McLinden, C. A., Richter, A., Kwok, R., Semeniuk, K., Kaminski, J. W., Gong, S.-L., Jarosz, J., Chipperfield, M. P., and Sioris, C. E.: Analysis of reactive bromine production and ozone depletion in the Arctic boundary layer using 3-D simulations with GEM-AQ: inference from synoptic-scale patterns, Atmos. Chem. Phys., 11, 3949-3979, https://doi.org/10.5194/acp-11-3949-2011, 2011.

Toyota, K., McConnell, J. C., Staebler, R. M., and Dastoor, A. P.: Air-snowpack exchange of bromine, ozone and mercury in the springtime Arctic simulated by the 1-D model PHANTAS Part 1: In-snow bromine activation and its impact on ozone, Atmos. Chem. Phys., 14, 4101-4133, https://doi.org/10.5194/acp14-4101-2014, 2014.

Wachsmuth, M., Gäggeler, H. W., von Glasow, R., and Ammann, M.: Accommodation coefficient of $\mathrm{HOBr}$ on deliquescent sodium bromide aerosol particles, Atmos. Chem. Phys., 2, 121131, https://doi.org/10.5194/acp-2-121-2002, 2002.

Wagner, T. and Platt, U.: Satellite mapping of enhanced $\mathrm{BrO}$ concentrations in the troposphere, Nature, 395, 486-490, https://doi.org/10.1038/26723, 1998.

Wennberg, P.: Bromine explosion, Nature, 397, 299-301, 1999.

Wren, S. N., Donaldson, D. J., and Abbatt, J. P. D.: Photochemical chlorine and bromine activation from artificial saline snow, Atmos. Chem. Phys., 13, 9789-9800, https://doi.org/10.5194/acp13-9789-2013, 2013.

Yang, X., Pyle, J. A., Cox, R. A., Theys, N., and Van Roozendael, M.: Snow-sourced bromine and its implications for polar tropospheric ozone, Atmos. Chem. Phys., 10, 7763-7773, https://doi.org/10.5194/acp-10-7763-2010, 2010.

Yang, X., Nedela, V., Runštuk, J., Ondrušková, G., Krausko, J., Vetráková, L., and Heger, D.: Evaporating brine from frost flowers with electron microscopy and implications for atmospheric chemistry and sea-salt aerosol formation, Atmos. Chem. Phys., 17, 6291-6303, https://doi.org/10.5194/acp-176291-2017, 2017. 